\title{
Opsonins and Dysopsonins of Nanoparticles: Facts, Concepts, and Methodological Guidelines
}

\author{
Emanuele Papini ${ }^{1,2 *}$, Regina Tavano ${ }^{1,2}$ and Fabrizio Mancin ${ }^{3}$ \\ ${ }^{1}$ Department of Biomedical Sciences, University of Padua, Padua, Italy, ${ }^{2}$ Centre for Innovative Biotechnological Research, \\ University of Padua, Padua, Italy, ${ }^{3}$ Department of Chemical Sciences, University of Padua, Padua, Italy
}

\section{OPEN ACCESS}

Edited by:

Paola Italiani,

National Research Council (CNR), Italy

Reviewed by:

Martin Himly,

University of Salzburg, Austria

Marco P. Monopoli,

Royal College of Surgeons in Ireland,

Ireland

*Correspondence:

Emanuele Papini

emanuele.papini@unipd.it

Specialty section:

This article was submitted to

Molecular Innate Immunity,

a section of the journal

Frontiers in Immunology

Received: 29 May 2020

Accepted: 25 August 2020

Published: 12 October 2020

Citation:

Papini E, Tavano $R$ and Mancin F (2020) Opsonins and Dysopsonins of Nanoparticles: Facts, Concepts,

and Methodological Guidelines.

Front. Immunol. 11:567365. doi: 10.3389/fimmu.2020.567365
Understanding the effects mediated by a set of nanoparticle (NP)-bound host biomolecules, often indicated with the umbrella term of NP corona, is essential in nanomedicine, nanopharmacology, and nanotoxicology. Among the NP-adsorbed proteome, some factors mediate cell binding, endocytosis, and clearing by macrophages and other phagocytes (opsonins), while some others display few affinities for the cell surface (dysopsonins). The functional mapping of opsonins and dysopsonins is instrumental to design long-circulating and nanotoxicologically safe next-generation nanotheranostics. In this review, we critically analyze functional data identifying specific proteins with opsonin or dysopsonin properties. Special attention is dedicated to the following: (1) the simplicity or complexity of the NP proteome and its modulation, (2) the role of specific host proteins in mediating the stealth properties of uncoated or polymercoated NPs, and (3) the ability of the innate immune system, and, in particular, of the complement proteins, to mediate NP clearance by phagocytes. Emerging speciesspecific peculiarities, differentiating humans from preclinical animal models (the murine especially), are highlighted throughout this overview. The operative definition of opsonin and dysopsonin and the measurement schemes to assess their in vitro efficacy is critically re-examined. This provides a shared and unbiased approach useful for NP opsonin and dysopsonin systematic identification.

Keywords: nanoparticle corona, nanoparticle proteome, nanoparticle phagocytosis, opsonin, dysopsonin, nanoparticle stealthing polymers, innate pattern recognition molecules, complement cascade

Abbreviations: MS, mass spectrometry; HRG, histidine-rich glycoprotein; HSA, human serum albumin; PMNGs, polymorphonuclear granulocytes; PLA, poly(D,L-lactic acid); PLGA, poly(lactic-co-glycolic acid); PCL, poly(varepsiloncaprolactone); PAMP, pathogen-associated molecular patterns; DAMP, damage-associated molecular patterns; VLDL, very low-density lipoprotein; SP-D, surfactant protein-D; DMBT1, deleted in malignant brain tumor 1; Kin-1, kininogen 1; C1q, complement factor $1 \mathrm{q}$; IgM, immunoglobulin M; HDL, high-density lipoprotein; BALF, bronchoalveolar lavage fluid; PAP, pulmonary alveolar proteinosis; SRCR, scavenger receptor cysteine rich; HMWK, high molecular weight kininogen; LDL, low-density lipoproteins; IgG, immunoglobulin G; FCS, fetal calf serum; PEG, polyethylene glycol; ORMOSIL, organically modified silica; PS, polystyrene; HES, hydroxyethyl starch; C3, complement factor 3; PMOXA, polymethyloxazoline; QD, quantum dot; MBL, mannose-binding lectin; HS, human serum; EGTA, ethylene glycol tetraacetic acid; EDTA, ethylene diamine tetraacetic acid; AP, alternative pathway of complement activation; CNT, carbon nanotubes; CMC-MWNT, carboxymethyl cellulose multiwall nanotubes; Ox-MWNT, oxidized multiwall nanotubes: FcR, receptor of the Fc fragment; SPIO-NW, superparamagnetic iron oxide nanoworms; AUT, 11-amino-1-undecanethiol; MUTA, 11-mercaptoundecyl tetraamine; $\alpha 2$ GP, alpha 2 human serum glycoprotein; PRM, pattern recognition molecules; C4, complement factor 4; C4BP, $\mathrm{C} 4 \mathrm{~b}$-binding protein; $\mathrm{CFH}$, complement factor $\mathrm{H}$; $\mathrm{FHr}$, factor $\mathrm{H}$ related. 


\section{INTRODUCTION}

In this review, we summarize the present-day knowledge concerning host proteins able to up- or downmodulate the capture of nanoparticles (NPs) by phagocytes and other cells. In doing this, we also aim at challenging too easy, simplified, straightforward, yet quite widespread, conceptions of the interactions of NPs with host molecules, mostly based on mass spectrometry (MS)/omics shot-gun analyses. Eventually, we propose methodological and conceptual guidelines for a more effective research in this field.

In the section "Introduction," we outline the historical emergence of the NP opsonin and dysopsonin concepts (section "The Discovery of Opsonin and Dysopsonin Activities Against Nanoparticles in Serum"), critically review the popular paradigm of the "NP corona," and discuss a more comprehensive and balanced view of the interactions between host molecules and NPs (section "The "Nanoparticle Corona" Paradigm and Its Limit”).

In section "Re-examination of the Complexity of the NP Proteome Composition," we address major methodological and conceptual issues relevant to assess the composition of the whole set of proteins binding to NPs. In particular, we highlight the pitfalls which may distort our view of the complexity of such phenomenon (section "Factors Overestimating the NP Proteome Complexity"). A milestone example is provided by the thoroughly discussed case of the NP proteome formed in bronchoalveolar lavage fluids (section "The Case of Bronchoalveolar Lavage Fluid-Derived NP Proteome"). Eventually, we show how the complexity of the set of NPbound proteins can be strongly influenced by the nanosurface availability, in a given protein solution (section "The NP Proteome as a Function of Nanosurface Availability").

In section "Influence on NP-Cell Interactions of specific NPBound Proteins," we review all the studies where defined host proteins have been proposed to display opsonic or dysopsonic activities and critically analyze the supporting evidence. This somehow provides a first overview, although still partial, on the possible major actors involved in the opsonin/dysopsonin equilibrium on NPs. Lipoproteins and apolipoproteins are discussed in section "Lipoproteins, Apo B100, Apo E, Apo A4, Apo C3, and Apo H," major proposed dysopsonins are treated in section "HRG, clusterin and HSA". Immune agonists are reviewed in section "Complement $\mathrm{C} 3$-derived Opsonins, $\mathrm{C} 1 \mathrm{q}$, MBL, Properdin, IgG, SP-A, and SP-D”.

In section "Methodolgical Approaches to Identify NP Opsonins and Dysopsonins," we list and critically evaluate the different methodologies applied in the present research to identify NP opsonins and dysopsonins, including cutting edge in silico approaches (section "Experimental Criteria") and propose a conceptual frame useful to measure, without bias, opsonin and dysopsonin activities (section "Minimizing Ambiguities in Attributing Opsonin or Dysopsonin Properties to NP-Bound Proteins").

In section "Opsonin-Dysopsonin Balance on Nanoparticles and Its Tilting by Complement," we eventually present our view on the dynamic interplay between the different host-derived proteins interacting at the bio-nano interface. This model distinguishes two separate aspects: the passive interaction of some host proteins with NPs, largely governed by thermodynamic parameters, and the active, catalytically driven, recruitment of the major complement opsonins.

\section{The Discovery of Opsonin and Dysopsonin Activities Against Nanoparticles in Serum}

The basic notion that host proteins can adsorb on nanoparticles (NPs) influencing their bioactivity has been present in literature for at least 30 years. Liposomes with different compositions and surface physicochemical features, which may be considered the prototypes of NPs, were first shown to selectively bind serum proteins able to influence their capture by phagocytes $(1,2)$. These studies and other related literature of the time clearly indicated that binding of plasma proteins to liposomal and polymeric NPs could be specific, depending on their surface chemical-physical properties. Recruited proteins were shown to dictate the biological fate of NPs, first of all endocytosis by phagocytes, and to represent a major aspect of NP host interaction, pharmacokinetics, and tissue targeting. In particular, Scieszka and Cho (4) early demonstrated that human serum busted the capture of nude liposomes by major blood professional phagocytes, the polymorphonuclear granulocytes (PMNGs), compared with the no-protein media. Notably, this effect was heat sensitive, being reduced at $56^{\circ} \mathrm{C}$, this property is diagnostic of complement-mediated NP opsonization (3). A general overview of the physiological importance and of the molecular mechanisms of NP internalization by phagocytes and non-phagocytes is given in the Box $\mathbf{1}$.

To prevent these adverse effects, pharmacologists soon developed specific liposome compositions and coatings, first of all conjugation with polyethylene glycol (PEG) or block copolymers like poloxamine-908, interfering with host protein adsorption on NPs $(4,5)$. The passivation of polystyrene (PS) and gold particles with these polymers was shown to decrease the binding of those serum opsonins favoring liver clearance by macrophage Kupffer cells and allowed the adsorption and action of specific, although not precisely identified, serum proteins with dysopsonic activities $(6,7)$. Among these, a protein with a $\mathrm{Mw}$ of $>100 \mathrm{kDa}$ was shown to be the major serum dysopsonin for PS NPs coated with poloxamine-908. In seminal studies dated back to the middle end of the 1990s of the past century, the first proteomic analysis was performed on liposomes, poly(D,Llactic acid) (PLA), and poly(lactic-co-glycolic acid) (PLGA) NPs using, at the time, advanced techniques like the 2D gels and mass spectrometry (MS). The goal of these investigations was establishing a functional correlation between specific proteins bound to nude or polymer-coated NP and their phagocyte clearance efficacy (8-10). Leroux et al. (8) found that plasma proteins are responsible for an increased uptake of nude PLA NPs by human monocytes, while for a decreased uptake by non-phagocytic lymphocytes, in vitro. Moreover, PEGylation of these particles inhibited their uptake by all cells in the presence of plasma proteins, and such stealth effect was tentatively ascribed to 


\begin{abstract}
BOX 1 | The different ways phagocytes and non-phagocytes deal with NPs and the implications for the pharmacological outcomes of NPs. The distinction between phagocytes (or professional phagocytes) and non-phagocytes is based on the presence in the first cell category of an internalization mechanism termed phagocytosis, absent in other cells. Phagocytosis relays on large sub-membrane cytoskeletal rearrangement, allowing the engulfment of particles normally in the micrometer range (microparticles), like bacteria. However, also nanometer-size viruses (nanoparticles) can be cleared by phagocytosis, possibly in aggregated state (e.g. immune complexes with specific antibodies; or due to surface clustering after binding to membrane receptors). Phagocytosis is typically performed by blood-circulating myeloid leukocytes, as polymorphonuclear granulocytes and monocytes, able to migrate in inflamed tissues. In addition, a set of tissue resident macrophages, overall forming the so-called RES or Reticular Endothelial System, and in particular the liver Kupfer cells and the splenic macrophages, can capture blood micro or nano particulates via phagocytosis. Liver and spleen phagocytes, and in some animals also lung macrophages, are mostly involved in the blood clearance of micro-nanoparticles with pharmacological medical function. Phagocytes associated to mucosal epithelia, such as bronchial-alveolar macrophages are especially relevant for clearance of inhaled NPs. Macrophages in liver are mostly responsible for the short blood half-life of these carriers, unless they are effectively modified to be "stealth", or not intercepted by phagocytes. The systemic activation of phagocytosis in blood is, on the contrary, excepted to determine adverse proinflammatory or pro-coagulant reactions and may contribute to HyperSensitivity Reactions upon NP administration.

Phagocytosis and clearance of NPs is functionally linked to the action of set of receptors, selectively expressed on phagocytes, which, once occupied by their ligands, indeed activate the phagocytosis mechanisms. FcRs and C3 receptors are the major responsible for the phagocytosis of particulates or immune-complexes decorated by Ig and complement derived opsonins C3d/C3bi. Several other membrane proteins expressed on phagocytes can bind to innate collectins (like MBLs, ficolins, C1q) or to molecular patterns present on microbes, altered cellular and proteins (e.g. scavenger receptors). Phagocytes are hence part of innate immune recognition and can also mediate elimination of particulates targeted by adaptive immunity (e.g. antibodies). Phagocytosis is a way to intracellularly confine potentially dangerous materials and microbes and,possibly, degrade and/or kill them.

Non-phagocytic cells are normally unable to activate the endocytosis of large microparticles or nanoparticles aggregates, since they only display what is called pinocytosis (cellular drinking), as opposed to phagocytosis (cellular eating). In pinocytosis, the invaginated membrane-bound vescicles have defined and small diameters which determine the cut-off or the dimension of the object to be internalized. For example, clatrin-mediated endocytosis has a cut off around 100-120 nm while caveolin-dependent endocytosis has a cut off of 40-90 nm. Several other pinocytic mechanisms are differently expressed in cells but rarely they can support the same ability, displayed by professional phagocytes, to engulf large particulates. A good example of the potential importance of nanoparticles capture by non-phagocytic cells is the endotheliocyte: here the internalization via clatrin mediated or caveolin mediated pathways has limited impact on NP blood half-life, due to the their much-reduced efficacy compared to macrophages capture rate and capacity (eg. Liver Kupfer cells). However, endothelial cell endocytosis may be critical for the extravasation (transcytosis) and the reaching by the NPs of their final target. This is particularly true for endotheliocytes of the Blood-Brian Barrier (BBB).

In conclusion, binding and internalization by phagocytes antagonize the NP action, mostly affecting their pharmacokinetics. This may also give rise to adverse effects. In this context, the binding of an opsonin is to be considered a critical event affecting long-circulation and biocompatibility of the nanoformulations. On the contrary, for non-phagocytic cells, and especially for endotheliocytes, the binding to a NP of ligands which can be internalized by receptor mediated endocytosis (e.g. HDL or transferrin), not necessarily is a negative pharmacological event and maybe, in some cases, even desirable.
\end{abstract}

the decreased absorption of apolipoprotein opsonins compared with their nude versions. Alleman et al. (11) observed a $\mathrm{Ca}^{2+}$ dependent enrichment of complement protein C3 on nude PLA NPs after incubation in serum and proposed a possible activation of complement mediated by immunoglobulin G (IgG; classical pathway), also abundantly observed on the NPs, so pointing the attention on complement factor 3 (C3)-derived opsonins as major players. Gref et al. (9) correlated the uptake of PEGcoated PLA, PLGA, and poly(varepsilon-caprolactone) (PCL) NPs by PMNGs in human plasma in vitro with PEGylation degree and protein adsorption. The total amount of plasma proteins absorbed on these NPs inversely correlated with PEG density grafting. Apolipoproteins and immunoglobulins were identified as possible major actors in regulating NP phagocytosis. The binding of both Apo C3 and Apo J, or clusterin, to PLGA NPs was shown to be drastically reduced by PEGylation (10).

Later on, it became clear that immune recognition systems may be critically involved in the binding of active triggers to PEG and other coats: for example, pre-existing anti-PEG antibodies [see, among others, (12)]. Also, lectins and other innate immune pattern recognition molecules (PRMs) were shown to bind to NPs and also to polymeric coats (13). Complement activation by the classical and the lectin pathways on the NP surface is often the result, with inflammation and phagocytosis. So, while the non-specific interaction and adsorption of proteins to NPs is governed by the laws of thermodynamic and electrostatics, it became evident that also the binding via specific binding sites, evolved in biological beings to monitor non-self or abnormal surfaces typical of microbes, or pathogen-associated molecular patterns (PAMPs), and of damage-associated molecular patterns (DAMPs) is critically involved in major biological effects of NPs (14-16).

Hence, the picture emerging at the beginning of the century, was that several serum proteins, could bind to NPs affecting their biological fate, favoring or reducing their capture by cells of the immune systems, or influencing their internalization in the target tissues.

\section{The "Nanoparticle Corona" Paradigm and Its Limit}

A generalized approach to characterize the composition and the function of NP-bound host proteins (and other biomolecules) emerged in the last decade thanks to comprehensive omics methodologies, such as the shot-gun. These studies prompted the formulation of the "NP protein (or biomolecule) corona" paradigm (17-22). Hundreds of polypeptide types have been reported to bind in different proportions to nanomaterials in host fluids and suggested to change the major physical-chemical, pharmacological, and biocompatibility features of NPs. The term corona originally evoked an almost continuous biomolecular interface between NPs and the host milieu, shielding the pristine nanomaterial surface and therefore creating new biological properties (23). However, subsequent research made the corona notion unfit to represent the whole range of possible NP-host molecule interactions. Indeed, a more heterogeneous spectrum of molecular assemblies/stoichiometry and architectures of the NP-protein complexes should be considered (Figure 1). For instance, it may be that few, but functionally effective, 


\section{$\mathrm{BIO}$ and MATERIAL}

INTERFACE
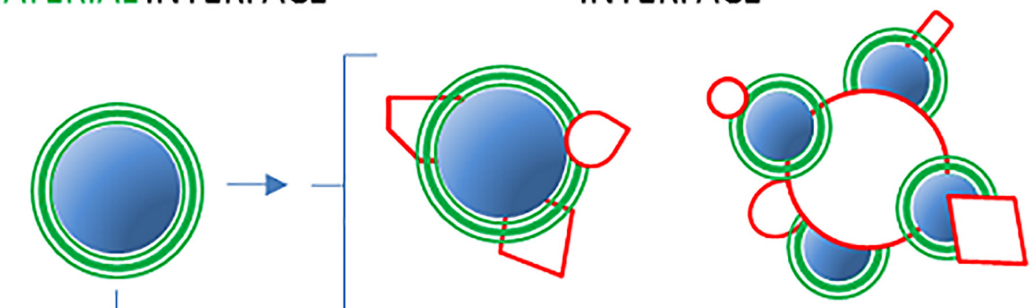

sparse biomolecules
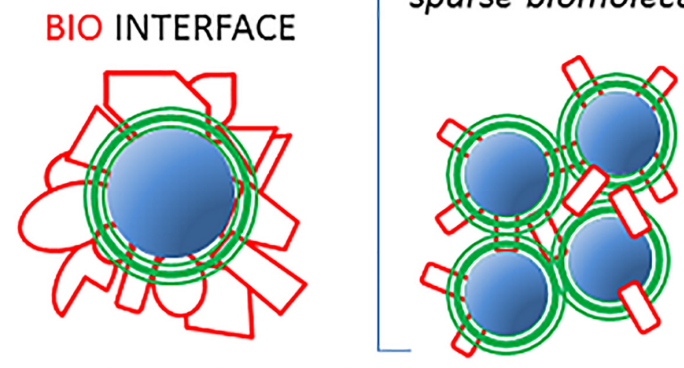

biomolecule NP

"corona"

biomolecule-

nanoparticle

aggregates

\section{NP biomolecule "corona"}

FIGURE 1 | Nanoparticle (NP)-host serum protein complexes may assume different configurations. A pristine material displaying a defined interface with its environment (green) can be assumed to be coated with an almost continuous layer of host proteins (red) when introduced in serum/plasma or BALF. This phenomenon corresponds to the original view of the so-called NP "hard" corona creating a new biointerface, "seen" by cells (23). Alternative configurations, represented on the left, may result in partial coverage of the NP material by fewer proteins with new biological properties mixed with the original material coat exposure. In addition, NP aggregates or inverted situations in which a large biomacromolecule is surrounded by smaller NPs could generate situations in which the concept of corona may be misleading or inappropriate.

proteins are interspersed among or even buried below a predominant polymeric NP coat (24). It could also be that the reciprocal topology of NPs and proteins may be difficult to define (e.g., large host proteins, such as very low-density lipoprotein (VLDL) (40 nm), oligomeric surfactant proteinD (SP-D; $100 \mathrm{~nm})$, or DMBT1 ${ }^{g p 340}$ (>200 nm) interacting with or even surrounded by a smaller "NP corona") or that unstructured protein-NP aggregates are formed. To avoid bias and include any possibilities, instead of using the term NP corona, we here prefer the neutral expression of NP proteome to indicate the whole set of NP-associated proteins. We will use preferentially the term NP proteome in the rest of this review. Yet, also, the largely used term NP corona, in its modern conception of a complex biomolecular structure formed upon the exposition of a non-natural surface to biological fluids, maintains its validity.

Evidence support that the composition of the NP proteome, considered as a whole, is important to determine the biological action of NPs [see, for example, (25), and references quoted therein]. However, it would be useful and mostly desirable to understand whether and which defined proteins, assembled with NPs, exert a specific and dominant modulatory action on NP phagocyte clearance and cell targeting. Such molecular identification is an obliged step for a focused screening of new NP surfaces allowing the best design of stealth and biosafe coatings.

Despite extensive research, the clear-cut mechanistic demonstration of the effect of well-defined components on
cell-NP interaction is limited. To assess this issue, we will here focus on recent literature in which the hypothetical role of specific NP-bound host proteins (serum/plasma and bronchial alveolar fluid) in cell association was functionally tested. In this analysis, we will also focus on the impact which may be derived from variations of the NP surface/protein concentration ratio on the composition and complexity of the NP proteome. We will pay special attention to data supporting the role of single proteins in decreasing (dysopsonin) or favoring (opsonin) the capture of NPs by macrophages and other phagocytes.

\section{RE-EXAMINATION OF THE COMPLEXITY OF THE NP PROTEOME COMPOSITION}

\section{Factors Overestimating the NP Proteome Complexity}

Understanding the role played by each single component among the NP proteome in cell interactions, and, in particular, with immune cells, may seem a very difficult task due to the high number (hundreds) of different polypeptide types which have been found to be associated with different NPs in variable proportions (19). A predominant popular view maintains indeed that the NP-associated protein ensemble is very complex in terms of chemical composition and, hence, displays very complex biological effects. 
However, based on simple geometric considerations, it seems that the estimated number of total polypeptide molecules per NP measured by shot-gun proteomics is, in many cases, much larger than the amount that could be accommodated on its surface (26). For example, the surface of a 20-nm diameter NP can host no more than 60 (and likely less) globular proteins with $5 \mathrm{~nm}$ diameter. Accordingly, it was experimentally found that one single 26-nm-diameter $\mathrm{SiO}_{2}$-NP maximally binds only about 27 fibrinogen (MW $340 \mathrm{kDa}$ ) or 30 HRG (histidine-rich glycoprotein; MW $70 \mathrm{kDa}$ ) or 47 kininogen 1 (Kin-1) molecules (MW $110 \mathrm{kDa}$ ) (27). Consistently, several, if not the majority, of the identified polypeptides in various NP-proteomes should be and are indeed found to be moderately or strongly substoichiometric $(19,28,29)$.

The presence of sub-stoichiometric proteins in the NPproteome is somehow surprising but can find different justifications. A first possible reason is the presence of NP subgroups within the same produced population with differentiated protein compositions due to variations of NP physicochemical features around the mean value (size, zeta potential). The perception of a strong heterogeneous composition of the NP proteome may also be derived from the improper equivalence between the terms polypeptide and protein made in data representations, which overlooks the quaternary structure of proteins and specific protein-protein interactions. For example, one $\mathrm{C} 1$ molecule, the first complement factor (C1q) of the classical cascade, is made by six $\mathrm{C} 1 \mathrm{qA}$, six $\mathrm{C} 1 \mathrm{qB}$, six $\mathrm{C} 1 \mathrm{qC}$, two $\mathrm{Cr}$, and two $\mathrm{Cs}$ polypeptides. Similarly, one IgM molecule, able to bind $\mathrm{C} 1$, comprises 10 heavy chains, 10 light chains-lambda or $\mathrm{k}$ isoforms - and one J chain. Hence, if we imagine a theoretical situation in which one single IgM/C1 complex is present on one NP, this will correspond to 10 different polypeptide types for a total of about 43 polypeptide molecules per NP. Informatics analysis restitutions also over-represents antibody complexity since all the different variables, $\mathrm{D}$ and $\mathrm{J}$, and constant segments contributing to the creation of different heavy and light chains of one specific immunoglobulin molecule, due to somatic recombination, are encoded by 148-171 genes in the human genome but are annotated as distinct proteins in data base (e.g., see Uniprot data base https://www.uniprot.org/). Even more importantly, the apoprotein part of lipoproteins, a major heterogeneous component associated with NPs $(30,31)$, comprises tens of different polypeptide types, often in sub-stoichiometric ratios (32). For instance, recent global proteomics analysis documented up to 90-100 polypeptides differently distributed in various high-density lipoprotein (HDL) size populations (33). Therefore, the NP proteome apparent complexity in serum/plasma might in part mirror the intrinsic proteome heterogeneity of NPbound lipoproteins.

Eventually, the high number of components found may also be due to residual contaminants after washing procedures with no functional meaning (34), possibly favored by NP aggregations.

What emerges from this analysis is that the NP proteome is not necessarily a complex and elusive ensemble of hundreds of proteins. We will see in the following paragraphs that, depending on NP nature, size, and on the experimental conditions, relatively simple NP proteomes may form, allowing in principle a relatively straightforward prediction of their properties.

\section{The Case of Bronchoalveolar Lavage Fluid-Derived NP Proteome}

A special, but physiologically central, case of NP-host protein interaction occurs when inhaled NPs enter the surfactant film covering the respiratory mucosae. Here, a dominant role in NP coating is also believed to be uniquely played by the lipid component of the surfactant film, with configurations which may strongly depend on the hydrophilicity or the hydrophobicity and lipid solubility of NP formulations [see (35) and other references therein quoted]. The first comprehensive analysis, based on shot-gun proteomics in porcine bronchoalveolar lavage fluid (BALF) from slaughtered animal lungs suggested a complex composition (about 400 different polypeptides) of the proteome associated to PLGA-, PEG-, and lipid-coated NPs (36). However, in this study, the first 25 most abundant polypeptide types bound to any of the used NP types, roughly representing the most part of the stoichiometric components (of total 376 polypeptides), accounted for $\sim 65 \%$ the "NP proteome" mass. Even more significantly, within this pool, cytoskeletal or cytosolic proteins, likely contaminants released by damaged cells, accounted for $\sim 48 \%$ of the total proteome mass, while the collectin surfactant proteins-A (SP-A), the major protein component of the pulmonary surfactant, represented about $2-4 \%$ of the total proteome mass.

This odd prevalence of intracellular proteins raises some concern on the real physiological composition of the BALFderived NP proteome as here characterized. Indeed, subsequent investigations, using human BALF from patients affected by pulmonary alveolar proteinosis (PAP) as a model, supported a different scenario (37). These authors pointed out that the collectin SP-A and other few major surfactant proteins accounted for a large fraction of total bound proteins and where consistently, stably, and abundantly associated with NPs, determining a relatively simple composition of the NP proteome formed in this host fluid.

It could be that part of discrepancies in these two studies derives from the different species and BALF isolation procedures (lung washes from slaughtered pigs versus therapeutic lung washes from live humans). Still, these studies highlighted the major role of innate PRMs in the interaction with inhaled NPs: the two collectin SP-A and SP-D and the product of deleted in malignant brain tumor 1 (DMBT1) gene. These are also major constituents of the NP proteome in bronchoalveolar fluid. The DMBT1 gene, thanks to alternative splicing mechanism, encodes for a family of glycoproteins involved in innate immunity and tissue repair at the mucosal level (38). The largest of the produced polypeptides $(340 \mathrm{kDa})$, called salivary agglutinin/glycoprotein340/DMBT1, secreted into bronchoalveolar surface lining fluid or in the saliva, contains 14 scavenger receptor cysteine-rich (SRCR) domains. It can agglutinate several Gram-negative and Gram-positive bacteria, interact with SP-A and SP-D and other immune agonists like $\mathrm{C} 1 \mathrm{q}$, sIgA, and lactoferrin and activate the complement cascade via the lectin pathway. 
Also, in the case of BALF, NP proteome compositions might be relatively simple, with a small number of predominant host proteins dictating the NP fate.

\section{The NP Proteome as a Function of Nanosurface Availability}

A quite obvious but often neglected consideration is that the ratio between the NP surface available and the concentration of potential NP binders influences the composition and the degree of complexity of the NP proteome. Indeed, it is likely that if the total surface is limited, because of low NP concentration, host-biomolecules having optimal affinity/concentration characteristics will compete more effectively for NP binding. This fact can potentially allow the detection of functional effects mediated by specific proteins at low NP concentrations, which did not reveal at high NP concentrations $(22,27,29)$.

Fedeli et al. (27) actually showed that the composition of the proteins bound to $\mathrm{SiO}_{2}$-NPs strongly depends on the NP concentration, and hence on the NP surface/serum protein ratio. In contrast with the main common view maintained in the field that hundreds of polypeptide types are found associated to a typical NP, below a certain NP concentration $(\sim 40 \mu \mathrm{g} / \mathrm{ml})$ the NP proteome of $26 \mathrm{~nm}$ diameter amorphous $\mathrm{SiO}_{2}-\mathrm{NPs}_{\mathrm{N}}$ in human plasma was largely formed by HRG (30 molecules/NPs), binding to silica with high affinity $\left(K_{\mathrm{d}}=2.4 \mathrm{nM}\right)$, and to a minor extent by the homologous protein high molecular weight kininogen (HMWK) (6 molecules/NP; $\left.K_{\mathrm{d}}=4 \mathrm{nM}\right)$. On the contrary, above $\sim 40 \mu \mathrm{g} / \mathrm{ml}$, a switch was observed in the NP proteome composition and other proteins were recruited forming a more complex proteome where fibrinogen, HDL and lowdensity lipoproteins (LDL), and IgG were major components. This switch can be explained assuming that human serum HRG is preferentially adsorbed at low NP doses; due to its high affinity, the silica surface, and that, after exhaustion of HRG consequent to NP concentration increase, space is left on the NP surface for the recruitment of other proteins with reduced affinity for silica. Accordingly, Francia et al. (29) showed that at low $(12 \mathrm{mg} / \mathrm{ml})$ serum content (i.e., high surface/serum ratio), $\mathrm{HDL}$ (Apo $\mathrm{AI}$ ) was the major component associated to $\mathrm{SiO}_{2}$-NPs $(300 \mu \mathrm{g} / \mathrm{ml}$ ) followed by HGR (17.9 and 5.4\%, respectively) while at high $(62 \mathrm{mg} / \mathrm{ml})$ serum content (i.e., low surface/serum ratios) HRG became the most abundant NP bound protein followed by Apo AI (9.5 and 7\%, respectively). The HRG prevalence in conditions of nanosurface limitation allowed to evidence its dysopsonic activity (27). In fact, $\mathrm{SiO}_{2}$ NP macrophage capture is substantially inhibited below $40 \mu \mathrm{g} / \mathrm{ml}$ $\mathrm{SiO}_{2}$-NP concentration. Purified HRG used at doses resembling the ones present in human serum inhibits macrophages capture as well, while HRG-depleted serum resulted in more effective NPs uptake by macrophages, which was abolished by restoration with purified HRG. It is also intriguing to observe that HRG depletion leads to the major recruitment of another protein, HMWK, which is homologous to HRG but devoid of intrinsic dysopsonic effects.

The above evidence proves that, at least in special NP/protein ratio conditions, or in special fluids (the BALF) and considering polypeptide structural assembly in proteins, the NP proteome may be indeed relatively simple and mostly represented by few stoichiometric protein types (Figure 2). Moreover, these data point the attention on the importance of NP dose and suggest that adsorption of proteins in conditions of high NP surface availability is less selective, since competition and reciprocal interference between serum proteins is less relevant. As a general trend, the composition of the NP proteome is predicted to be more heterogeneous at high (roughly $\mathrm{mg} / \mathrm{ml}$ ) NP concentrations (i.e., increased surface/serum concentration ratio) and tends to be less specific compared with serum composition, especially for highly absorbing nanomaterials like silica.

The above example is also interesting because it highlights a major difference between the human and the mouse serum. In fact, the transition from a simple HRG-enriched proteome to a complex fibrinogen/HDL-enriched one, observed at NP doses of $>40 \mu \mathrm{g} / \mathrm{ml} \mathrm{SiO}_{2}$-NPs in human serum, is not observed up to $400 \mu \mathrm{g} / \mathrm{ml} \mathrm{SiO}_{2}$-NPs in mouse serum. This observation predicts that the amount of HRG in mice is much higher. This represents a case in which the NP-concentration dependence of the NP proteome is species specific due to the peculiar characteristic of the serum of this mammal compared with the human being. It is not impossible that other qualitative and quantitative differences in the serum composition differently modulate its biological effects (including phagocytes capture) in humans and major preclinical models. In line with this concept, the proteome associated to bare or PEGylated $\mathrm{SiO}_{2}-\mathrm{NPs}$ was found to be significantly different in human and mouse serum $(27,39)$.

\section{INFLUENCE ON NP-CELL INTERACTIONS OF SPECIFIC NP-BOUND PROTEINS}

In parallel with the explosion of the corona idea, several studies identified protein agonists favoring or inhibiting the capture of NPs by phagocytes and non-phagocytes (Figure 3). However, it is important to note that the first evidence of a defined opsonin for phagocytes, complement C3b, was obtained in 1995-1997, immediately after the identification of the general phenomenon of host protein influence on NPs, and in concomitance with the early proteomic characterizations. Below, we review such evidences, also summarized in Tables 1, 2, and their strength, based on protein types or broad classes.

\section{Lipoproteins, Apo B100, Apo E, Apo A4, Apo C3, and Apo H}

Blood lipoproteins are major components associated to several NP types (22). Fedeli et al. (40) showed that purified human HDLs increase the capture of $\mathrm{SiO}_{2}$-NPs by human macrophages but not by human monocytes. In this study the exhaustion of HDL from the surface of $\mathrm{SiO}_{2}$-NPs above a critical NP dose also induced necrotic effects in macrophages. However, HDL role in the whole complex serum mixture is still hypothetical since no evidence from HDL-depleted sera was provided. Based on 


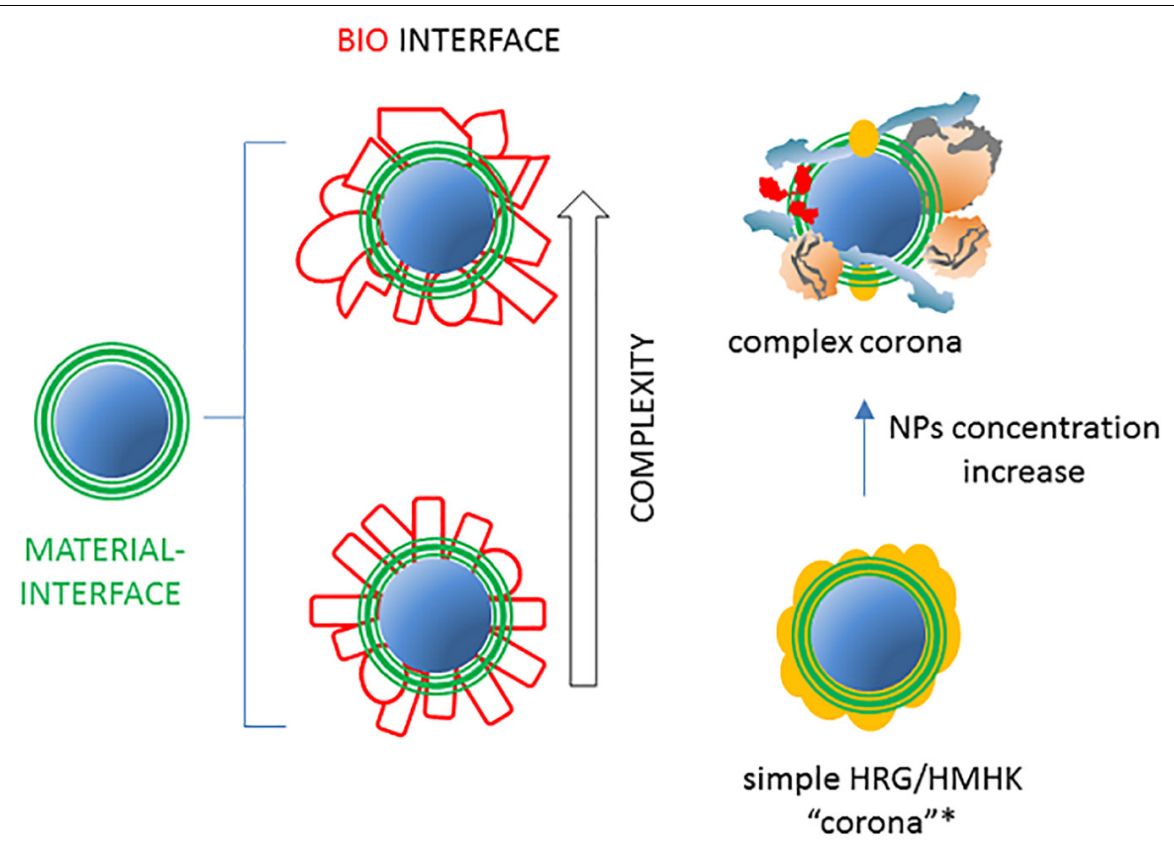

*Fedeli et al. Nanoscale 2015

FIGURE 2 | The NP-associated proteome may have various degrees of complexity. As represented on the left, the complexity of the set of NP-bound proteins after incubation with complex host fluids is assumed to be high in terms of numbers of different polypeptides and of total bound molecules. Evidence suggests that in some conditions, the NP proteome may be simpler, i.e., formed by few molecular species in a more limited number. An example is represented on the right where the NP concentration decrease in human plasma, due to stronger reciprocal competition for the diminishing available surface, results in the conversion of a relatively complex and heterogeneous NP proteome into a simple and more homogeneous one, characterized by the prevalence of HRG and HMWK (27).

\section{ofunctional studies: opsonin ; dysopsonin}

\section{phagocytes}

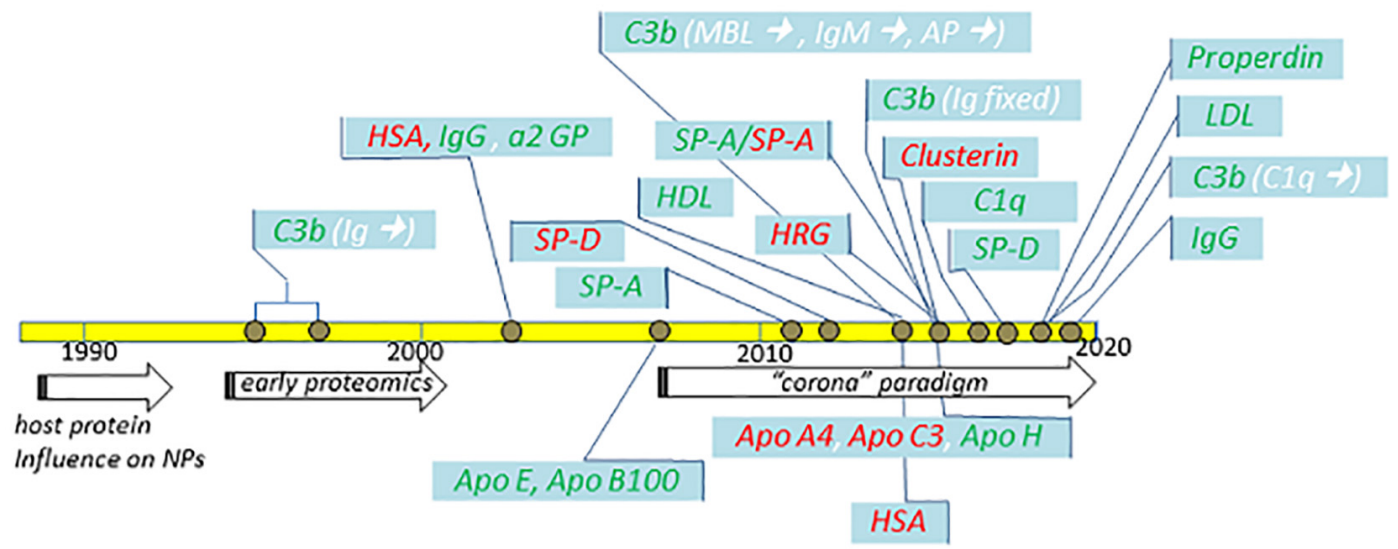

non phagocytes

FIGURE 3 | Schematic summary of major functional studies in the last 32 years suggesting the identification of specific NP opsonins and dysopsonins. The indicated studies (detailed in the text) and their publication years are compared with major general achievements (arrows) in the fields. Dysopsonins are in red, while opsonins are in green. In the case of C3b opsonin, the complement triggers are indicated in white within brackets. Studies performed using phagocytes are on top, while studies performed using epithelial or endothelial cells are on the bottom. 
TABLE 1 | Proteins with NP opsonin or dysopsonin properties in phagocytes.

\begin{tabular}{|c|c|c|c|c|c|c|}
\hline Protein & NPs ( size) & Activity & Cellular model & Functional evidence & $\begin{array}{l}\text { Relevant or } \\
\text { critic notes }\end{array}$ & References \\
\hline $\begin{array}{l}\text { High Density } \\
\text { Lipoproteins } \\
\text { (HDL) }\end{array}$ & $\mathrm{SiO}_{2}(26 \mathrm{nM})$ & Opsonin & $\begin{array}{l}\text { Macrophages } \\
\text { differentiated from } \\
\text { human blood } \\
\text { monocytes }\end{array}$ & $\begin{array}{l}\text { Effect of purified lipoprotein } \\
\text { compared to human serum } \\
\text { albumin (HSA) }\end{array}$ & & $\begin{array}{l}\text { Fedeli et al. } \\
(40)\end{array}$ \\
\hline $\begin{array}{l}\text { Histidine Rich } \\
\text { Glycoprotein } \\
\text { (HRG) }\end{array}$ & $\mathrm{SiO}_{2}(26 \mathrm{nM})$ & Dysopsonin & $\begin{array}{l}\text { Macrophages } \\
\text { differentiated from } \\
\text { human blood } \\
\text { monocytes }\end{array}$ & $\begin{array}{l}\text { Effect of purified protein } \\
\text { compared to other purified } \\
\text { plasma proteins/plasma } \\
\text { depletion - reconstitution }\end{array}$ & $\begin{array}{l}\text { Complement } \\
\text { inhibited (citrated } \\
\text { plasma) }\end{array}$ & $\begin{array}{l}\text { Fedeli et al. } \\
(27)\end{array}$ \\
\hline \multirow[t]{2}{*}{ Clusterin/Apo J } & $\begin{array}{l}\text { PEG or PEEP coated } \\
\text { polystyrene NPS } \\
(100 \mathrm{~nm})\end{array}$ & Dysopsonin & $\begin{array}{l}\text { Mouse RAW264.7 } \\
\text { macrophagic cell line }\end{array}$ & $\begin{array}{l}\text { Effect of the purified protein } \\
\text { compared to no protein } \\
\text { medium and purified HSA }\end{array}$ & $\begin{array}{l}\text { Control HSA used } \\
\text { at } \\
\text { non-physiological } \\
\text { dose; human } \\
\text { protein versus } \\
\text { murine cells }\end{array}$ & $\begin{array}{l}\text { Schöttler } \\
\text { et al. (45) }\end{array}$ \\
\hline & $\mathrm{SiO}_{2}-\mathrm{NPs}(70 \mathrm{~nm})$ & & & & & \\
\hline $\begin{array}{l}\text { Human serum } \\
\text { albumin (HSA) }\end{array}$ & $\begin{array}{l}\text { Differently charged } \\
\text { polystyrene }(1 \mu \mathrm{M})\end{array}$ & Dysopsonin & Human dendritic cells & $\begin{array}{l}\text { Effect of purified human serum } \\
\text { albumin compared to purified } \\
\text { lgG and } \alpha 2 \text { GP and to no } \\
\text { protein }\end{array}$ & Microparticle & $\begin{array}{l}\text { Thiele et al. } \\
(50)\end{array}$ \\
\hline \multirow[t]{5}{*}{ co3b/iC3b } & $\begin{array}{l}\text { ORMOSIL PMOXA NPS } \\
(100 \mathrm{~nm})\end{array}$ & Opsonin & $\begin{array}{l}\text { M-CSF differentiated } \\
\text { macrophages from } \\
\text { human blood } \\
\text { monocytes, human } \\
\text { blood monocytes and } \\
\text { PMNGs }\end{array}$ & $\begin{array}{l}\mathrm{Ca}^{2+} \text { dependence/ } \\
\text { complement factors depleted } \\
\text { sera- } \\
\text { reconstitution/complement } \\
\text { neutralizing } \\
\text { antibodies/statistical correlation }\end{array}$ & $\begin{array}{l}\text { C1q directly } \\
\text { bound to NPs } \\
\text { triggers } \\
\text { complement }\end{array}$ & $\begin{array}{l}\text { Tavano et al. } \\
(28)\end{array}$ \\
\hline & $\begin{array}{l}\text { Dextran-coated } \\
\text { SPIO-NWs (110 nM); } \\
\text { LipoDox (100 nm, } \\
\text { PEGylated liposomes); } \\
\text { Onivyde (120 nm, } \\
\text { PEGylated } \\
\text { liposomes);SPIO } \\
\text { Feraheme }\end{array}$ & Opsonin & Human macrophages & & $\begin{array}{l}\text { C3b/iC3b fixed on } \\
\text { anti NPs "natural" } \\
\text { lgG }\end{array}$ & Vu et al. (69) \\
\hline & $\begin{array}{l}\text { Iron Oxide Nano } \\
\text { Worms }\end{array}$ & Opsonin & $\begin{array}{l}\text { Mouse peritoneal } \\
\text { macrophages, } \\
\text { neutrophils, monocytes } \\
\text { and lymphocytes; } \\
\text { human neutrophils, } \\
\text { monocytes, } \\
\text { lymphocytes and } \\
\text { eosinophils }\end{array}$ & $\begin{array}{l}\mathrm{Ca}^{2+} \text { dependence/complement } \\
\text { factors depleted sera- } \\
\text { /complement neutralizing } \\
\text { antibodies/Lectin inhibitory } \\
\text { sugar }\end{array}$ & $\begin{array}{l}\text { MBL triggered } \\
\text { (mouse); MBL } \\
\text { and AP triggered } \\
\text { in human, } \\
\text { sporadically also } \\
\text { natural IgM } \\
\text { triggered }\end{array}$ & $\begin{array}{l}\text { Banda et al. } \\
\text { (62) }\end{array}$ \\
\hline & & & & & & $\begin{array}{l}\text { Wang et al. } \\
(81)\end{array}$ \\
\hline & & & & & & $\begin{array}{l}\text { Inturi et al. } \\
\text { (63) }\end{array}$ \\
\hline $\mathrm{C} 1 \mathrm{q}$ & $\begin{array}{l}\text { CMC-MWNT, } \\
\text { Ox-MWNT } \\
(10-20 \mathrm{~nm} \times 5-20 \mu \mathrm{M})\end{array}$ & Opsonin & $\begin{array}{l}\text { U937 cells and human } \\
\text { macrophages }\end{array}$ & $\begin{array}{l}\text { Effect of purified protein } \\
\text { compared to no-protein media }\end{array}$ & $\begin{array}{l}\text { purified subunits } \\
\text { of } \mathrm{C} 1 \mathrm{q} \text { separately } \\
\text { induce the same } \\
\text { effect of entire } \\
\text { protein }\end{array}$ & $\begin{array}{l}\text { Pondman } \\
\text { et al. (66) }\end{array}$ \\
\hline Properdin & $\begin{array}{l}\text { Carboxyl-methyl } \\
\text { cellulose coated CNT }\end{array}$ & Opsonin & $\begin{array}{l}\text { THP-1 macrophagic } \\
\text { human cell line }\end{array}$ & $\begin{array}{l}\text { Effect of purified protein } \\
\text { compared to no protein } \\
\text { medium }\end{array}$ & $\begin{array}{l}\text { independent on } \\
\text { complement } \\
\text { activation }\end{array}$ & $\begin{array}{l}\text { Kouser et al. } \\
(68)\end{array}$ \\
\hline
\end{tabular}


TABLE 1 | Continued

\begin{tabular}{|c|c|c|c|c|c|c|}
\hline Protein & NPs ( size) & Activity & Cellular model & Functional evidence & $\begin{array}{l}\text { Relevant or } \\
\text { critic notes }\end{array}$ & References \\
\hline \multirow[t]{3}{*}{$\lg G$} & $\mathrm{SiO}_{2}-\mathrm{NPs}(100 \mathrm{~nm})$ & Opsonin & HEK-293T & Fc receptor overexpression & $\begin{array}{l}\text { non-phagocytic } \\
\text { cells expressing } \\
\text { FcR as phagocyte } \\
\text { model }\end{array}$ & $\begin{array}{l}\text { Lara et al. } \\
(41)\end{array}$ \\
\hline & PLGA based NPs & Opsonin & $\begin{array}{l}\text { mouse RAW } 264.7 \\
\text { macrophagic cell line } \\
\text { and } \mathrm{CHO}-\mathrm{K} 1\end{array}$ & $\begin{array}{l}\text { FcR negative and positive cell } \\
\text { lines }\end{array}$ & $\begin{array}{l}\text { murine } \\
\text { phagocytes as } \\
\text { FcR + cells and } \\
\text { hamster } \\
\text { non-phagocytes } \\
\text { as FcR - cells; } \\
\text { human plasma }\end{array}$ & $\begin{array}{l}\text { Rezaei et al. } \\
(70)\end{array}$ \\
\hline & Polystyrene (1 $\mu \mathrm{M})$ & Opsonin & Human dendritic cells & $\begin{array}{l}\text { Effect of purified human lgG } \\
\text { compared to purified HSA }\end{array}$ & & $\begin{array}{l}\text { Thiele et al. } \\
(50)\end{array}$ \\
\hline \multirow[t]{4}{*}{ SP-A } & $\begin{array}{l}\text { Amine-modified } \\
\text { cationic PS (100-200 } \\
\text { and } 500 \mathrm{~nm})\end{array}$ & Opsonin & $\begin{array}{l}\text { Mouse alveolar } \\
\text { macrophages and RAW } \\
264.7 \text { macrophagic cell }\end{array}$ & $\begin{array}{l}\text { Effect of purified proteins } \\
\text { compared to no protein media }\end{array}$ & & $\begin{array}{l}\text { Mc Kenzie } \\
\text { et al. (73) }\end{array}$ \\
\hline & $\begin{array}{l}\text { Anionic PS NPs } \\
(100-200 \text { and } 500 \mathrm{~nm})\end{array}$ & Dysopsonin & & & & \\
\hline & $\begin{array}{l}\text { Variously coated } \\
\text { magnetite NPs } \\
(110-180 \mathrm{~nm})\end{array}$ & Opsonin & $\begin{array}{l}\text { Murine alveolar } \\
\text { macrophages }\end{array}$ & $\begin{array}{l}\text { Effect of purified protein } \\
\text { compared to BSA }\end{array}$ & & $\begin{array}{l}\text { Ruge et al. } \\
(74)\end{array}$ \\
\hline & $\begin{array}{l}\text { Mannosilated PEG on } \\
\text { PLGA/PLA NPS } \\
(140 \mathrm{~nm})\end{array}$ & Opsonin & $\begin{array}{l}\text { Murine alveolar } \\
\text { macrophages; TPH-1 } \\
\text { macrophagic human } \\
\text { cell line }\end{array}$ & $\begin{array}{l}\text { Effect of purified protein } \\
\text { compared to no protein }\end{array}$ & $\begin{array}{l}\text { alveolar } \\
\text { macrophages } \\
\text { capture in vivo }\end{array}$ & $\begin{array}{l}\text { Ruge et al. } \\
(77)\end{array}$ \\
\hline \multirow[t]{3}{*}{ SP-D } & $\begin{array}{l}\text { CMC-CNT } \\
(10-20 \mathrm{~nm} \times 5-20 \mathrm{~mm})\end{array}$ & Opsonin & $\begin{array}{l}\text { U937 and THP-1 } \\
\text { human cell line }\end{array}$ & $\begin{array}{l}\text { Effect of purified protein } \\
\text { compared to no protein }\end{array}$ & & $\begin{array}{l}\text { Pondman } \\
\text { et al. (79) }\end{array}$ \\
\hline & $\begin{array}{l}\text { OxCNT } \\
(10-20 \mathrm{~nm} \times 5-20 \mathrm{~mm})\end{array}$ & Dysopsonin & & & & \\
\hline & $\begin{array}{l}\text { CMC-CNT }(10- \\
20 \mathrm{~nm} \times 5-20 \mathrm{~mm})\end{array}$ & Opsonin & $\begin{array}{l}\text { Murine alveolar } \\
\text { macrophages and lung } \\
\text { dendritic cells }\end{array}$ & $\begin{array}{l}\text { Comparison of SP-D } \\
\text { containing BALF with SP-D } \\
\text { lacking one }\end{array}$ & $\begin{array}{l}\text { capture in vivo } \\
\text { using control or } \\
\text { SP-D Knock Out } \\
\text { transgenic mice }\end{array}$ & $\begin{array}{l}\text { Kendall } \\
\text { et al. (80) }\end{array}$ \\
\hline
\end{tabular}

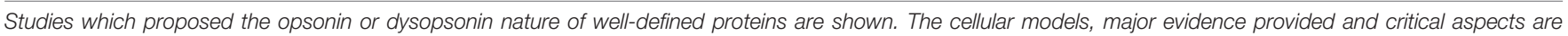

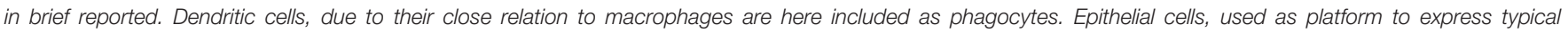

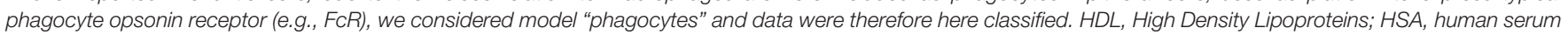

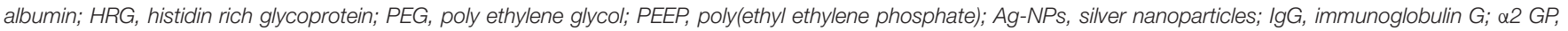

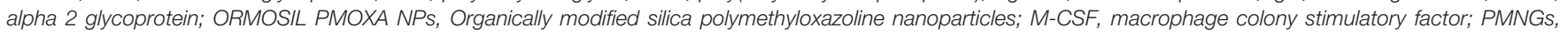

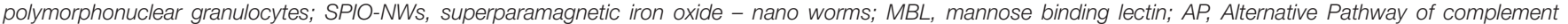

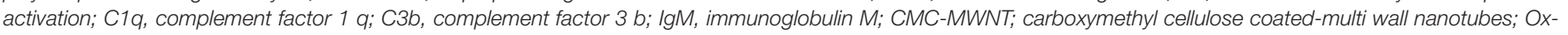

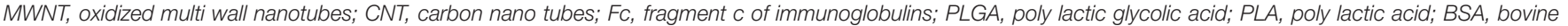

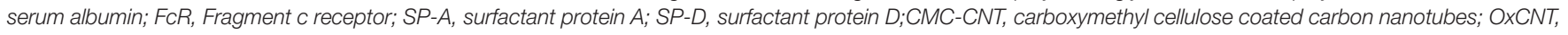
oxidized carbon nanotubes; BALF, bronchial alveolar lavage fluid.

indirect evidence, LDL Apo B 100 was proposed to be critical for the uptake of $\mathrm{SiO}_{2}$-NPs via the LDL receptor (41). Although purified human LDLs were found to mediate the capture of $\mathrm{SiO}_{2}$ NPs by human macrophages, while not by human monocytes and non-phagocytic lymphocytes (27), similar effects were also displayed by several other $\mathrm{SiO}_{2}-\mathrm{NP}$-associated serum proteins [HDLs, VLDLs, Kin-1, fibrinogen, IgG, and human serum albumin (HSA)]. When all these proteins were mixed, the lack of none of them resulted in loss of macrophage capture. This suggests that all these proteins (included LDL), although endowed with intrinsic pro-phagocytic affects in macrophages, are interchangeable in their function, being hence sufficient but not necessary to the pro-opsonic effect in macrophages. Ritz et al. (42) proposed that Apo A4 and Apo C3 counteract NP mesenchymal and cancer cell targeting, based on their presence in the proteome of COOH-derivatized PS NPs in human serum and on the ability of these purified apolipoproteins to induce a strong decrease of cell capture (80\% inhibition) compared with bare NPs. However, the functional effect of lipid-free apolipoproteins is questionable since, in physiological conditions, Apo A4 and Apo C3 are part of VLDL, L(a), and LDL whole proteolipid complexes. This caveat does not apply to the proposed opsonin Apo $\mathrm{H}$ (also called beta-2-glycoprotein 1) which, despite its name, only partially adsorbs to lipoproteins and is largely free in serum and which, as purified agonist, was shown to induce a twofold increased cellular uptake of NPs compared with no-protein media conditions (42). Purified Apo E and Apo B100 have also been shown to improve the endocytosis of poly(ethylene glycol) polyhexadecylcyanoacrylate (PEG-PHDCA) NPs in primary rat brain endothelial cells 
TABLE 2 | Proteins with NP "opsonin" or "dysopsonin" properties in non-phagocytes.

\begin{tabular}{|c|c|c|c|c|c|c|}
\hline Protein & NPs ( size) & Activity & Cellular model & Functional evidence & $\begin{array}{l}\text { Relevant or critic } \\
\text { notes }\end{array}$ & References \\
\hline $\begin{array}{l}\text { Low density } \\
\text { lipoprotein (LDL) } \\
\text { Apo B100 }\end{array}$ & $\mathrm{SiO}_{2}-\mathrm{NPs}(100 \mathrm{~nm})$ & Opsonin & $\begin{array}{l}\text { Human A549 } \\
\text { cells/HEK-293T cells }\end{array}$ & $\begin{array}{l}\text { LDLR downregulation } \\
\text { (siRNA)/expression }\end{array}$ & & Lara et al. (41) \\
\hline \multirow[t]{2}{*}{ Apo B100 Apo E } & $\begin{array}{l}\text { poly(ethylene glycol) } \\
\text { polyhexadecylcyanoacrylate } \\
\text { (PEG-PHDCA) NPs } \\
(135-171 \mathrm{~nm})\end{array}$ & Opsonin & $\begin{array}{l}\text { Primary rat brain } \\
\text { Endothelial cells }\end{array}$ & $\begin{array}{l}\text { Effect of the purified } \\
\text { protein compared to } \\
\text { NPs alone; block by } \\
\text { anti-LDLR mAb }\end{array}$ & $\begin{array}{l}\text { 5\% FBS present in all } \\
\text { conditions; no lipid } \\
\text { component }\end{array}$ & Kim et al. (43) \\
\hline & & & & & & Kim et al. (44) \\
\hline Apo A4 & $\begin{array}{l}\mathrm{COOH} \text { modified } \\
\text { polystyrene NPs (100 nm) }\end{array}$ & Dysopsonin & $\begin{array}{l}\text { Human cancer cell line } \\
\text { (HeLa)[Frame1] and } \\
\text { primary human } \\
\text { mesenchymal stem } \\
\text { cells (hMSCs) }\end{array}$ & $\begin{array}{l}\text { Effect of the purified } \\
\text { Apo proteins compared } \\
\text { to no protein media }\end{array}$ & $\begin{array}{l}\text { Recombinant apo } \\
\text { proteins separate from } \\
\text { the lipid components }\end{array}$ & Ritz et al. (42) \\
\hline Apo C3 & & Dysopsonin & & & & \\
\hline Apo $\mathrm{H}$ & & Opsonin & & & & \\
\hline HSA & $\begin{array}{l}\text { Dihydrolipoic } \\
\text { acid-coated -QDs (5 nm) }\end{array}$ & Dysopsonin & $\begin{array}{l}\text { Human cancer cell line } \\
\text { (HeLa) }\end{array}$ & $\begin{array}{l}\text { Effect of the purified } \\
\text { protein compared to no } \\
\text { protein }\end{array}$ & & Treul et al. (51 \\
\hline
\end{tabular}

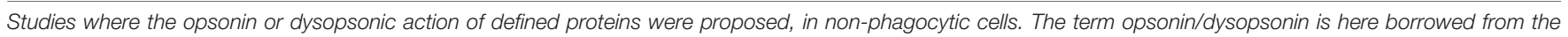

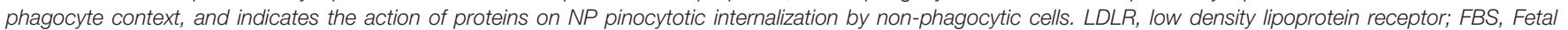
Bovine Serum; QDs, quantum dots; HSA, human serum albumin.

(RBEC), compared with NPs only, via specific binding to cellular LDL receptors $(43,44)$.

\section{HRG, Clusterin, and Albumin}

As anticipated above, Fedeli et al. (27) showed that HRG has dysopsonic effects on $\mathrm{SiO}_{2}-\mathrm{NPs}$, based on several evidences. First, when the HRG amount in the NP proteome drops, due to NP dose increase and HRG exhaustion in plasma, NP capture by macrophages improves in parallel. Additionally, the single purified protein used at physiological doses was shown to act as dysopsonin, while the whole set of other major NP proteome components (HMWK, HDL, LDL, VLDL, IgG, fibrinogen, and HSA) used all together or in several combinations had no dysopsonic action. HRG-depleted plasma lost the HS antiopsonic effect at low NP doses, which was regained upon purified HRG reintroduction in the system. Indeed, HRG effectively competed also with fetal calf serum (FCS) proteins impeding their association to NPs, blocking the macrophages capture of NPs observed in this medium. However, experiments were performed in citrated plasma, where $\mathrm{Ca}^{2+}$-dependent complement pathway is inhibited and eliminated from the scenario (see below).

Special attention must be dedicated to clusterin since this chaperonin (also called Apo J) has been proposed to play a fundamental role in conferring the so-called stealth feature, or ability to avoid NP-clearance by capturing macrophages (45). Selvestrel et al. (46) already showed that, while HRG was the major protein associated to inorganic $\mathrm{SiO}_{2}-\mathrm{NPs}$ as discussed above, clusterin was the major protein bound to organically modified silica (ORMOSIL) NPs after incubation in human serum. Using PEG or poly(ethyl ethylene phosphate)-coated PS NPs, Schöttler et al. (45) proposed that the ability of these polymers to confer NP stealth characteristics was not directly due to the polymer itself but, rather, to its ability to effectively bind and recruit clusterin on NPs. This would correspond to a paradigm shift since clusterin as a dysopsonin would have the final responsibility for the macrophage escape ability of polymercoated NPs. The possibility of a specific affinity of clusterin for NP PEG coating is however not supported by other studies. Early studies already discussed reported that clusterin binding to PLGA NPs in human plasma was totally abrogated after PEGylation of these NPs (10). In several other cases, as the ORMOSIL NPs above cited, clusterin binds to NPs also in the absence of a PEG coating.

Aoyama et al. (47) found that clusterin is a major component also on uncoated silver and silica NPs. In both studies, purified human clusterin demonstrated some intrinsic stealthing power at physiological serum concentration $(50 \mu \mathrm{g} / \mathrm{ml})$ compatible with whole serum effect. However, control experiments with the major plasma protein albumin, to show clusterin specificity, were not homogenous since being performed at a dose (50 $\mu \mathrm{g} / \mathrm{ml}$ ) that is $\sim 1000$ times reduced compared with its physiological serum concentration $(\sim 60 \mathrm{mg} / \mathrm{ml})$. Simon et al. (48) showed that clusterin binding to PEG-coated PS NPs was inhibited by pretreatment of human plasma and serum at $56^{\circ} \mathrm{C}$ and that this resulted in a higher binding of NPs to murine RAW264.7 macrophages, in line with the major antiopsonic effect of clusterin. However, although purified clusterin reintroduced in preheated serum was found to partially bind back to NPs, the restoration of stealth effect was not assessed. Interestingly, in the same study, the authors also showed that human serum/plasma increased the capture of hydroxyethyl starch (HES) nanocapsules by macrophages and that this paralleled the deposition of complement protein $\mathrm{C} 3$ on NPs. Thermal $\left(56^{\circ} \mathrm{C}\right)$ serum treatment strongly reduced both complement protein NP association, in agreement with heat sensitivity of the complement cascade (49), and NP 
macrophage capture. Since serum heat pretreatment also strongly abolished the binding of clusterin to NPs, a phenomenon which should result in a stronger cell uptake, data suggest that the loss of NP opsonization by $\mathrm{C} 3$ was functionally predominant on the parallel disappearance from the NP surface of the supposedly stealthing/dysopsonin clusterin. At the end, clusterin was apparently neither necessary nor sufficient to mediate the stealth action of serum in this case, and its presence on NPs was not useful to predict phagocyte capture evasion. On the contrary, this study supported a much more solid correlation between murine macrophage capture and complement activation. Consistently, Tavano et al. (28) observed strong and similar clusterin binding to uncoated PEG, and polymethyloxazoline (PMOXA)-coated ORMOSIL NPs in human serum, but this medium improved macrophage capture of polymer-coated NPs and not of the bare ones. Moreover, this study showed that $\mathrm{Ca}^{2+}$ sequestration selectively and totally abrogated complement activation and phagocyte capture of coated NPs but did not grossly affect the abundance of clusterin in the NP proteome. Eventually, comparing the effect of different sera from different donors, macrophage capture efficacy positively statistically correlated with the extent of $\mathrm{C}$ activation and C3b NP opsonization but did not negatively correlate with clusterin presence on NPs.

The presence of serum dysopsonin antagonizing opsonins was suggested quite early (6). Being albumin the most abundant serum protein, studies focused on this protein. Thiele et al. (50) showed that purified HSA strongly decreases the phagocytosis of PS microparticles with various surface charges by dendritic cells and also antagonized the opsonic action of IgG and $\alpha 2$ human serum glycoprotein, using mixtures of these purified factors. More recently, HSA was shown to decrease the capture of dihydrolipoic acid-coated- quantum dots (QDs) by HeLa cells compared with the no-protein medium (51). The consensus is that indeed native HSA is a dysopsonin for NPs, but this is largely based on studies performed with the purified protein used alone or in combination with few other opsonins. However, no evidence is available on the biologically relevance of serum albumin for NPs in complex media like serum. Nevertheless, presently, HSA is one of the most promising components for effective drug carriers and nanotheranostics $(52,53)$.

\section{Complement C3-Derived Opsonins, C1q, MBL, Properdin, IgG, SP-A, and SP-D}

It is long known that complement-derived C3 opsonins $(\mathrm{C} 3 \mathrm{~b} / \mathrm{iC} 3 \mathrm{~b})$ are major factors determining the binding of microbial particles to phagocytes in blood, tissues, and clearing organs (liver, spleen, lungs) $(54,55)$. Experiments dated back to mid-1990s of the past century first clearly pointed that adsorption of C3-derived opsonins on poly(D,L)-lactic acid NPs, likely via a $\mathrm{Ca}^{2+}$-dependent IgG-triggered pathway (classical pathway), mediates phagocytosis by monocytes (56). Several data show that also PEGylated and many other NPs can activate the complement pathway, leading to C3-derived opsonin deposition mediating their clearance (57-59). This adverse phenomenon may be due to immune recognition of nanomaterial surface portions mimicking microbial or altered cell surfaces, which in turn triggers complement cascade and NP clearance (60). In vitro experiments in HS showed the role of complement and of the C3-derived opsonins in phagocyte interaction. Three major lines of evidence are normally used: (1) the sensitivity of pro-opsonic action of serum to chelating agents sequestrating $\mathrm{Ca}^{2+}$ (EGTA plus $10 \mathrm{mM}$ $\mathrm{MgCl}_{2}$ ) and so blocking the classical and lectin pathways, or the full block of complement by EDTA which sequestrates both $\mathrm{Ca}^{2+}$ and $\mathrm{Mg}^{2+}$, so inhibiting also the complement alternative pathway (AP) (61); (2) the use of C3 (and other C proteins) depleted sera, with reintroduction of the purified protein as supercontrol $(28,62,63)$; and (3) the neutralizing effect of complement-specific monoclonal antibodies $(28,62,63)$. In other cases, selective monosaccharide blockers of differentiated lectin pathways were also used to prevent the association of $\mathrm{MBL}$ or ficolins to polymer-coated NPs (62). There is presently a strong record showing that in many instances, it is indeed the antibody-mediated or the innate-triggered complement pathway that leads to deposition of $\mathrm{C} 3 \mathrm{~b} / \mathrm{iC} 3 \mathrm{~b}$ opsonins on NPs. These factors seem to actually dominate the effect of other supposed NP alternative opsonins or dysopsonins. Using mouse sera selectively deprived of $\mathrm{C}$ factors allowed to demonstrate that dextrancoated superparamagnetic iron oxide nanoworm (SPIO-NW) phagocytosis by mouse peritoneal macrophages in vitro is due to collectin MBL-mediated C3b opsonization $(63,64)$. Tavano et al. (28) showed that C1q, the major collectin-mediating antibodydependent $\mathrm{C}$ activation, can directly bind to PMOXA-coated ORMOSIL NPs leading to $\mathrm{C} 3 \mathrm{~b} / \mathrm{iC} 3 \mathrm{~b}$ opsonization and phagocyte endocytosis via a $\mathrm{Ca}^{2+}$-dependent mechanism. Selective $\mathrm{C} 1 \mathrm{q}$ depletion of human serum abrogated C3 opsonization, while purified $\mathrm{C} 1 \mathrm{q}$ reintroduction restored $\mathrm{C} 3$ opsonization and macrophage capture. Eventually, comparative analysis of the NP proteome after incubation with sera from different individuals revealed a statistically significant positive correlation between macrophage capture and the relative amounts of $\mathrm{C} 3$ and other C proteins on NPs. Manipulating the presence of $\mathrm{Ca}^{2+}$ and $\mathrm{Mg}^{2+}$ selectively blocked $\mathrm{C}$ activation, leaving all the rest of the NP proteome almost untouched. Interestingly, clusterin, the major proposed dysopsonin was indeed a major protein in the $\mathrm{NP}$ proteome, again showing that the presence of $\mathrm{C} 3 \mathrm{~b} / \mathrm{iC} 3 \mathrm{~b}$ in NPs was enough to abrogate any possible dysopsonic action of clusterin. Data support that when C3 opsonin is activated on NPs, it plays a dominant role over clusterin and any other serum protein dysopsonic power.

The direct NP binding by collectin C1q, originally considered only able to mediate antibody or CRP-dependent complement activation, fits with its role also as a direct PRM involved in clearing of microbial or altered self-antigens (64). Consistently, innate recognition by $\mathrm{Clq}$ of $\mathrm{Gd} @ \mathrm{C}_{82}(\mathrm{OH})_{22}$ NPs, leading to complement activation, was documented in lung cancerpersonalized NP proteome (65). The pattern recognition properties of $\mathrm{Clq}$ ensured binding also to carbon nanotube (CNT) and triggered complement activation and phagocytosis by macrophages. Recombinant, purified C1q was shown to bind carboxymethyl cellulose multiwall nanotubes (CMC-MWNT) or oxidized multiwall nanotubes (Ox-MWNT) determining a 4- and 1.3-fold capture increase, respectively, by U937 cell 
line and human macrophages compared with the no-protein medium (66). However, it is strange that the three different globular head monomers were also shown to separately induce an enhanced endocytosis comparable with that of full $\mathrm{C} 1 \mathrm{q}$ in CMC-MWNT. C1q also effectively bound to PEG-grafted CNTs, but not on CNTs with adsorbed PEG, without triggering the complement cascade (67). However, in this study, no cellular uptake assays were performed to assess the direct opsonic action of bound C1q.

Properdin also displays direct innate recognition of NPs, a fact leading to potent proinflammatory activation of macrophages. Properdin up-modulates (1.4-fold) the endocytosis of carboxylmethyl cellulose-coated CNT by a TH-1 macrophagic cell line independently from $\mathrm{C}$ activation, a pro-opsonic action which can account that of the whole serum (1.6-fold increase). Such effect is mediated by properdin TSR 4 and TSR 5 domains, since recombinant forms of these proteins competitively inhibited the effect of native properdin (60\% inhibition) (68).

In another study, it was shown that clinical and preclinical NPs are recognized by "natural" pre-existing antibodies and that labeling of NP-bound IgG by C3b/iC3b opsonins is crucial for an effective capture by phagocytes (69). The use of FcR-negative or overexpressing cell lines also indirectly suggested that NP-bound antibodies mediate cell interaction with phagocytes $(41,70)$.

Importantly, such recognition systems do not totally overlap in humans and closely related preclinical species like the mouse, a fact negatively impacting on nanomedical translation efficacy. Dextran-coated SPIO-NW where opsonized by $\mathrm{C} 3 \mathrm{~b} / \mathrm{iC} 3 \mathrm{~b}$ via a MBL-triggered lectin pathway, amplified by the alternative (factor B dependent) loop, in mouse serum. Instead, in human serum, the same NPs triggered both lectin and APs, and in some subjects, an IgM-dependent classical pathway, all contributing to $\mathrm{C} 3 \mathrm{~b} / \mathrm{iC} 3 \mathrm{~b}$ deposition and opsonization (62). Polymethyloxazoline NPs did not activate $\mathrm{C}$ through direct $\mathrm{Clq}$ binding in mouse serum as it was in the human serum (28). It is likely that functional divergence characterizes the reaction to nanoformulations in contact with serum from other relevant preclinical models, like the pig, compared with humans. Species specificity of the NP proteome and especially of its immune recognition side emerges as a major critic and still poorly investigated aspect.

Although strong attention is paid to the interaction of NP with serum/plasma proteins, a phenomenon occurring after blood administration, the possible role of biomolecules binding to inhaled particle entering in contact with the bronchoalveolar fluid lining the respiratory mucosae, is also of paramount importance in nanotoxicology and nanomedicine. Also in this case, the host component may influence, NP toxicity, phagocyte clearance and tissue interaction or translocation (71).

Very interestingly, specific innate oligomeric collectins operate in this thin fluid layer: SP-A and SP-D can interact with PAMP or DAMP materials in the lung and also with NPs, favoring their agglutination, phagocytosis, while mediating an anti-inflammatory action (72). Several studies, generally based on protocols testing the effect of purified SPs on the capture of relevant NPs by alveolar macrophages or other phagocytes and APCs, strongly suggest that bronchoalveolar collectins are major innate PRMs influencing the bioactivities of inhaled nanosystems.

McKenzie et al. (73) showed that purified SP-A inhibited the uptake of amine-modified cationic PS NPs by alveolar macrophages, while it favored the uptake of unmodified anionic PS NPs. This is quite a relevant information showing how the same agonist can be judged to be dysopsonic or opsonic depending on the physical-chemical characteristics of the pristine NP surface. Ruge et al. (74) showed that purified SP-A at $10 \mu \mathrm{g} / \mathrm{ml}$ (compatible with BALF SP-A concentration, see (75), mediated the association to alveolar macrophages of magnetite NPs (110-180 nm) coated with different polymers and molecules (starch, carboxymethyldextran, chitosan, poly-maleic-oleic acid, phosphatidylcholine) which was significantly stronger than that observed in the presence of a concentration of BSA $(1 \mathrm{mg} / \mathrm{ml})$ indeed much greater than that measured in BALF (76). Mannosilated PEG chains grafted on NPs improved TPH1 macrophage cell capture in the presence of purified SP-A (77). Several metal-oxide NPs when incubated with porcine BALF adsorbed with various efficacy SP-A (78), however no cell-capture experiments were performed. Purified SP-D induced a moderate upmodulation of CMC-CNT phagocytosis, while a symmetrical small downregulation of $\mathrm{Ox}-\mathrm{CNT}$ phagocytosis, compared with the uptake in the no-protein media (79). This is again a case in which, depending on the nanosurface chemicalphysical features, one protein can act either as an opsonin or as a dysopsonin. SP-D (rhSP-D) bound to oxidized and carboxymethyl cellulose (CMC)-coated CNTs via its C-type lectin domain and enhanced phagocytosis by U937 and THP-1 cell lines (80).

\section{METHODOLGICAL APPROACHES TO IDENTIFY NP OPSONINS AND DYSOPSONINS}

\section{Experimental Criteria}

The results discussed in the previous paragraphs reveal the complexity of the biological response to NP proteome formation. Consequently, it is of paramount importance to approach the study of the role of the NP proteome components with a rigorous and well-defined approach, which will necessarily require multiple evidences. Based on the above data, the following criteria are proposed to assess the specific and dominant role of those host proteins which are consistently and reproducibly present in the NP proteome.

\section{Statistic Correlation and Informatics Modeling}

Significant correlation between the relative abundance of a given factor in the NP proteome formed from different donors' sera and cell-interaction parameters may be a valuable, although not sufficient per se, information to support its functional role in cell interaction. For example, a bioinformatics-inspired multivariate model using the NP proteome fingerprints of 

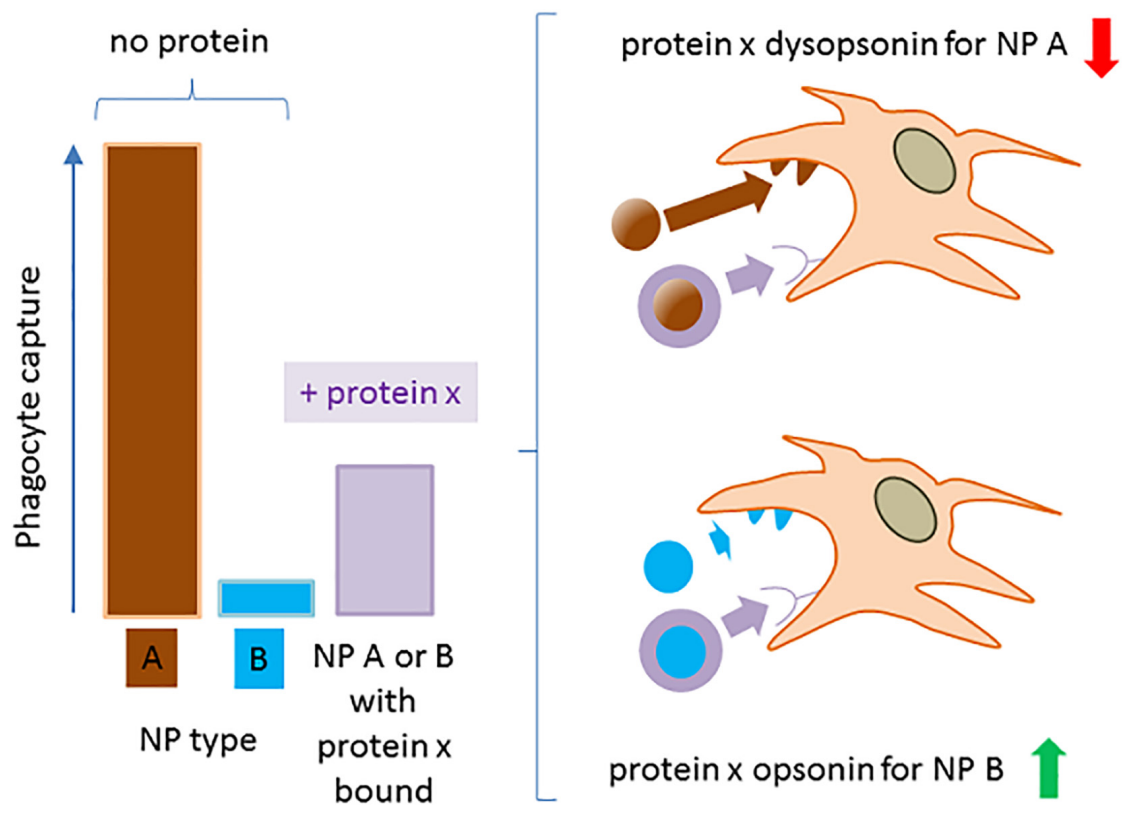

FIGURE 4 | The operative definition of a NP-bound protein as opsonin or dysopsonin may be biased. The scheme summarizes how NPs with a very different ability to be captured by phagocytes in the absence of proteins, can be differently modified by the same protein, leading to a controversial classification of its opsonic or dysopsonic action.

a large set of NPs implicated a hyaluronan-binding protein as positive mediators of NP-A549 human lung epithelial carcinoma cell interactions (20). However, NP-cell association of cationic AUT- and MUTA-modified 15-nm gold NPs is only weakly reduced by the presence of high concentrations of free hyaluronic acid as competitive inhibitor (20-25\% inhibition), indicating that unidentified hyaluronan-independent mechanisms are prevalent. This corroborates that correlative or statistic relationships alone, although useful to generate working hypothesis, are not enough to assess the role of specific NP proteome components and do not necessarily imply causality.

\section{Functional Effect of Purified Components}

This evidence may demonstrate the intrinsic opsonic or dysopsonic activity of a given protein, chosen on the basis of its abundance in the NP proteome, its known physiological relevance, or arbitrarily. However, the biological relevance of the tested factor remains to be assessed, since other proteins could play the same role or be functionally dominant. Selected serum proteins (such as albumin, IgG) should be used at concentrations mimicking those present in the body fluids (e.g., HSA, $60 \mathrm{mg} / \mathrm{ml}$; IgG, 7$10 \mathrm{mg} / \mathrm{ml}$ ). Due to its special composition, where SP-A and SP-D are indeed major protein components, in the bronchoalveolar fluid, the specific role of defined NPinteracting molecules may appear easier to characterize than in serum/plasma. Here, the effect of single purified SPs, shown in several investigations, is therefore a stronger indication of their dominant and biologically relevant role as opsonins or dysopsonins. However, it should also be remembered that the functional contribution of the lipidic component of the surfactant, not always contemplated in these studies, is predicted to be important to modulate SP action on NPs.

\section{Depletion}

The selective elimination of specific factors, with consequent loss of the effect induced in control host fluids, is a much stronger evidence, compared with the use of the same factors alone. This information can be obtained by immune depletion with specific antibodies or using sera from KO mouse. However, a super control based on the reintroduction of the purified protein should be included, whenever possible, to rule out non-specific artifacts due to plasma or genetic manipulations. Here, it should also be noted that accurate functional and proteomic control of the effect of depletion on the rest of the NP proteome should also be performed to evidence possible rearrangements due to the loss of specific proteome components or to the methodology used for depletion. For example, the procedure to delipidate serum from lipoproteins also eliminates clusterin from the NP proteome in ORMOSILNPs and abolishes complement activity in serum (Tavano and Papini, unpublished results).

\section{The Use of Specific Inhibitors}

Specifically recognized inhibitors of innate recognition molecules may be used to ascertain their role in NP 


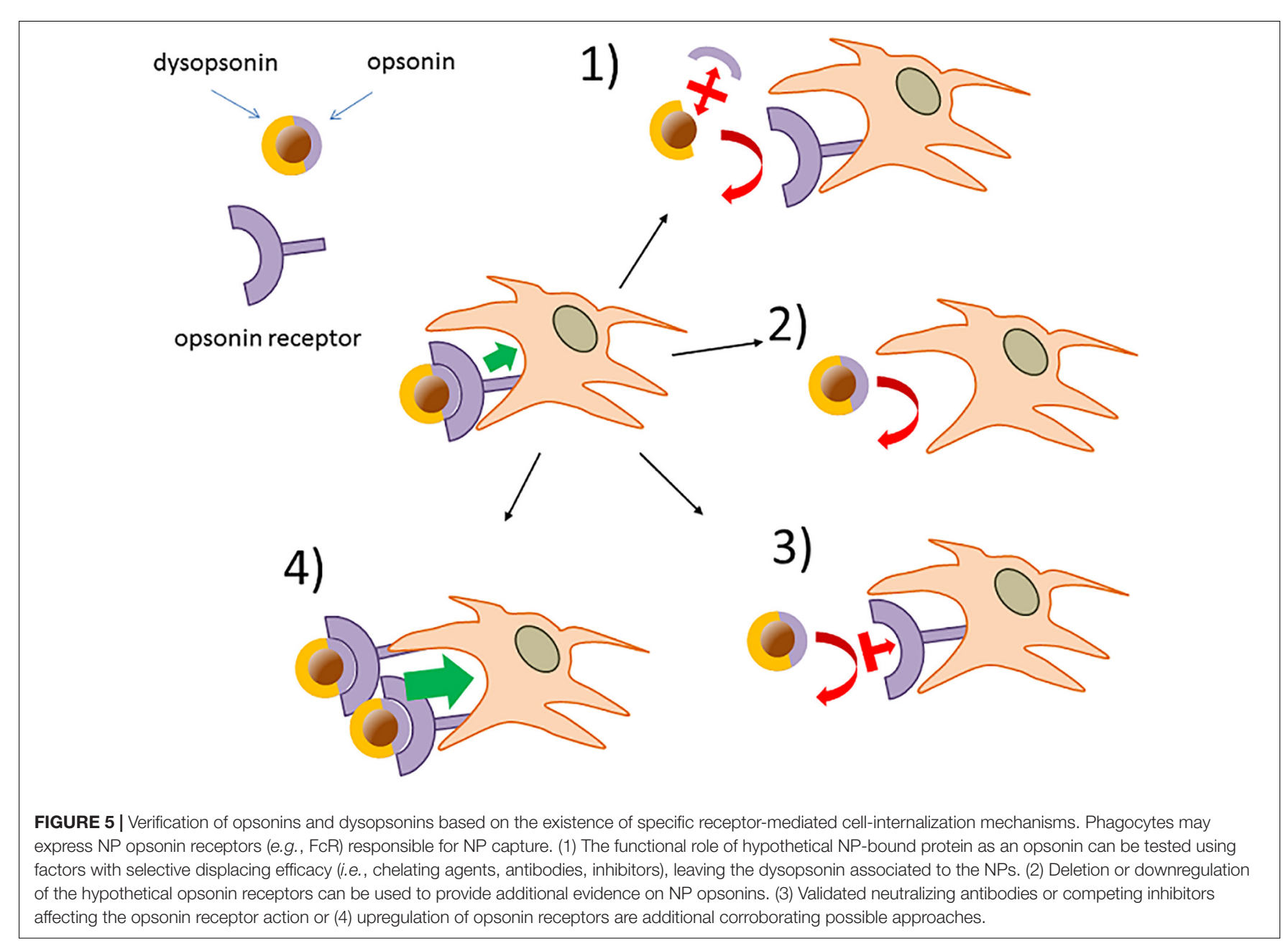

binding and endocytosis induction. For example, sugar monosaccharides as $N$-acetyl-glucose and mannose can compete with collectins (62). However, proper control must be performed to exclude wrong mechanistic conclusions and to define the real direct opsonic actor. In particular, comprehensive shot-gun proteomics with quantification of single NP proteome composition should be controlled to exclude secondary recruitment of phagocytosis-active agonists after prevention of a given putative active molecule on NPs. Similarly, the efficacy of the complement cascade and of $\mathrm{C} 3 \mathrm{~b} / \mathrm{c} 3 \mathrm{bi}$ opsonin deposition should be checked after incubation of inhibitors. Neutralizing monoclonal antibodies may also be also valuable tools, as it was shown for anticomplement-specific antibodies.

\section{Affecting Cell Receptors for NP-Proteome Components}

One indirect way to prove the role of a bound NP protein could be the downregulation of specific receptors, for example, by RNA interference or gene mutation or their overexpression due to transfection procedures in appropriate model cells. Also, receptor neutralization by specific antibodies or competition with protein domains is applicable. Again, this may be a useful additional evidence to support the specific action of a single proteome component.

\section{Minimizing Ambiguities in Attributing Opsonin or Dysopsonin Properties to NP-Bound Proteins}

Available data suggest the convenience of refocusing in more detail on the very notions of dysopsonin or opsonin in the nanofield, generally assumed as self-evident. If we look at literature, we may in fact sometimes assist conflicting conclusions on the intrinsic pro- or antiphagocytic activity of defined proteins. Excluding trivial experimental non-reproducibility, part of such discrepancies may stem from the way we measure opsonin/dysopsonin activity and on our limited perspective on the models used. Indeed, the classification of a given host protein binding to NPs as an opsonic or a dysopsonic agent may be ambiguous if only based on the relative cell capture of NPs in the presence of this single protein, compared with the NP capture in the no-protein media. In fact (as exemplified in Figure 4), the intrinsic ability of the new nanohost interface to regulate phagocyte internalization could be higher, lower, or equal to the one expressed by the nude original 
affinity-driven proteins

(dysopsonins and adaptive and innate direct opsonins/complement triggers)

\section{catalytically driven complement proteins} (C3b/iC3b opsonized NP)

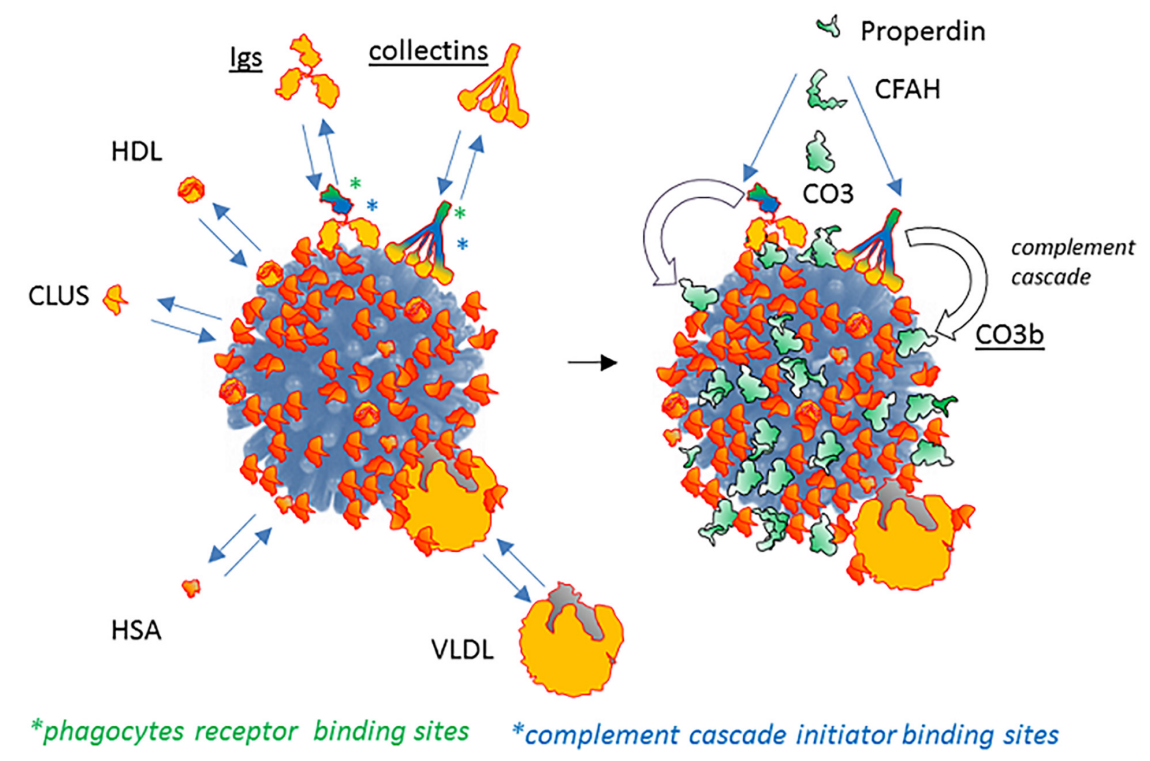

FIGURE 6 | The contribution of passive host proteins binding and of active complement cascade in modeling opsonin/dysopsonin balance and the final phagocyte capture of NPs. Present literature suggests that some host proteins potentially able to bind NPs (left) are dysopsonin since they do not mediate the binding of the NP to receptors and clearing by macrophages or monocytes (e.g., HSA, clusterin, HRG). On the contrary, other proteins (in general, belonging to the adaptive or innate immune system, like immunoglobulins, collectins, properdin, surfactant proteins) do bind to phagocyte-expressed receptors, being potential opsonins. Both molecule classes (dysopsonins and direct opsonins) associate to NPs thanks to a chemical equilibrium regulated by their affinity/avidity for determined chemical features of the NP coats. The right panel shows how the immune agonists recognizing the NP surface as antigenic or as microbial/altered self danger signals not only can be directly opsonizing but can also trigger the enzymatically driven complement cascade by activating protease transductors, like C1 or MASPs, eventually leading to a C4-dependent generation of C3b/iC3b major opsonin, covalently fixed on the NP surface.

particles, depending on their pristine chemical composition. For example, nothing prohibits that a protein may decrease the intrinsic binding to cells and phagocytes of a highly interactive nanomaterial, and that, on the contrary, the same protein could increase the binding of another, intrinsically more inert material. Moreover, different materials could induce diverse conformational modifications or denaturation processes of the same protein, which may result in changes of its cellbinding efficacy.

A situation exemplifying such case is present in early studies by Thiele et al. (50), where the cell capture of microparticles $(1 \mu \mathrm{M})$ with different charges and surface properties was measured in the no-protein media or in the presence of three selected serum proteins. All proteins tested ( $\alpha 2$ human serum glycoprotein/ $\alpha 2$ GP, IgG, and HSA) decreased the strong capture of cationic particle compared with the no-protein medium, so apparently acting as dysopsonins. However, when more hydrophobic and less capture-prone particles where used, $\alpha 2$ GP and IgG improved particle capture compared with the no-protein medium, while HSA still acted as a strong dysopsonin, also able to compete with $\alpha 2 \mathrm{GP}$ and IgG opsonic action. This clearly indicates that one protein could look like opsonic or dysopsonic depending on the characteristic efficacy of the pristine material to interact with cells and suggests that the comparison with cell-capturing efficacy in the no-protein media to classify a protein as dysopsonin or opsonin could be sometimes misleading. Hence, it may be much more biologically relevant and pharmacokinetically predicting to define the possible action of a given protein based on the measurement of specific ligand/receptor interactions, favoring endocytosis/phagocytosis. In such case, what is relevant is the comparison of the NPcell interaction and the consequent cell endocytosis in controls and in samples where, due to experimental manipulation or natural situations, the well-delineated receptor-mediated effect is inhibited or absent. Such comparison is less prone to bias if it is performed in more physiological conditions allowing also the binding of other proteins (such as full serum, BALF) (e.g., annihilation of C3b-C3b receptor complex formation by divalent ion deprivation to block complement in serum). Therefore, it may be safer and less prone to bias to define an opsonin as a molecule able to mediate the binding of a given NP to cells through a defined, and possibly identified, receptor (Figure 5). Consequently, the biological relevance of such phenomenon, within the general context, may be tested in vitro, by assessing its relative effect compared with the efficacy of cell capture after its experimental selective inhibition. 


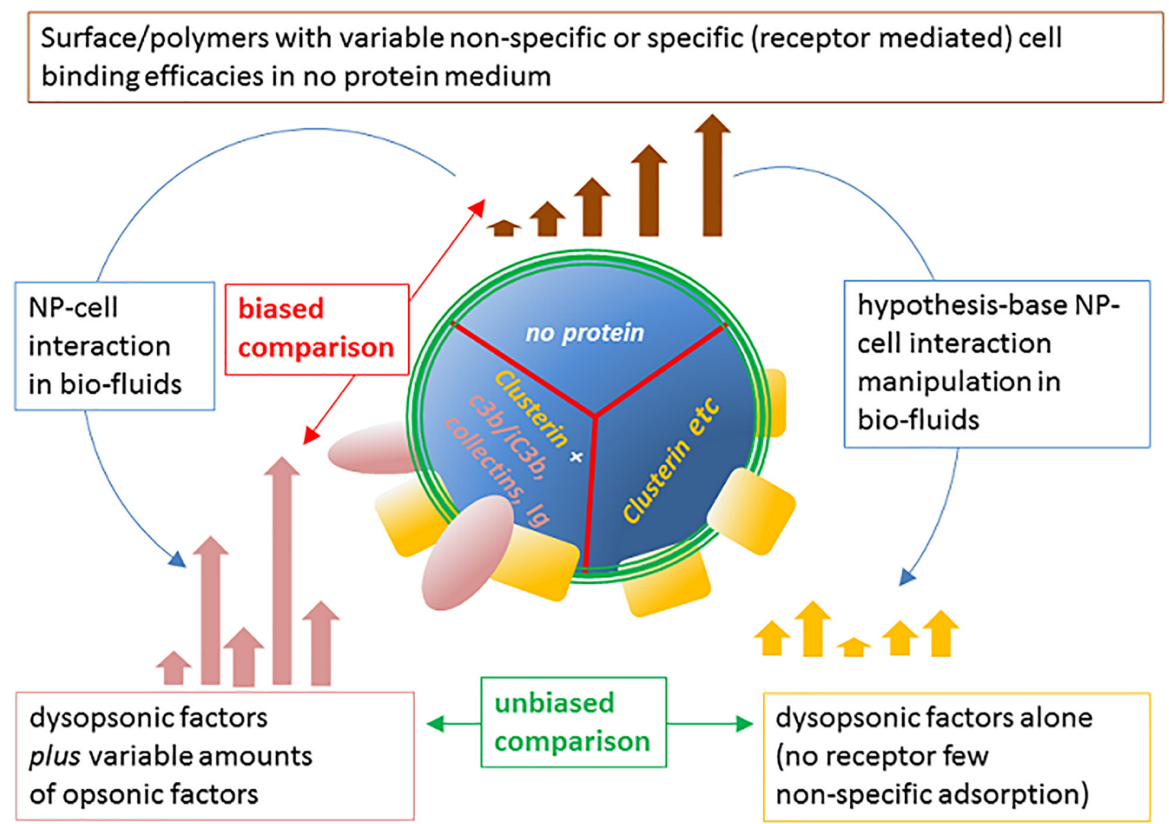

FIGURE 7 | Modulation of NP cell-capture efficacy spectrum of the pristine material surface by host NP proteome and proper approach to identify opsonins. The intrinsic ability of NP chemical coatings to mediate the internalization by phagocytes can vary significantly, depending on charge, hydrophobicity, or other specific characteristics of the coating agents and polymers. The resulting spectrum of clearance efficacy (top) of possible surfaces in the no-protein medium is modified by the possible binding of host proteins to NPs in biofluids (left). This may result in up-modulation, down-modulation, or non-modulation of one defined NP cell capture compared with the one in the no-protein medium. However, the selective hampering of opsonins in complex medium, differently modulates the capture spectrum (right), allowing to evaluate the capture efficacy due to remaining dysopsonins. This comparison allows to unequivocally define the biological relevance in vitro of the identified specific opsonic factors and obtain relevant insights on the molecular mechanisms involved.

\section{OPSONIN-DYSOPSONIN BALANCE ON NANOPARTICLES AND ITS TILTING BY COMPLEMENT}

With the above caveat, recent literature broadly indicates the following scheme of NP-host serum/BALF effect on phagocytosis. A pristine material, either nude or derivatized with supposed stealthing polymers, is in general phagocytosed less, although not necessarily depending on the material type, when major dysopsonins associate at the host interface (e.g., clusterin or HSA). However, the parallel binding of specific innate or adaptive immune proteins can generally overcome the protective effect of clusterin or other dysopsonic serum proteins by acting as direct opsonin or by activating the complement cascade leading to the deposition of the major opsonin C3b/C3bi. In such scenario (depicted in Figure 6 and discussed in detail in the relative legend), the whole spectrum of variable phagocytosis efficacies mediated by different pristine coatings with differentiated intrinsic direct cell-binding mechanism "collapse" to a narrower and more reduced capture efficacy range. This may happen, for example, if host factors like clusterin or HSA, with similar shielding and stealth efficacy, bind similarly to a wide range of NPs. However, as we have pointed out in this review, in physiological conditions, part of the residual surface not engaged with dysopsonins may bind antibodies or innate PRMs, directly acting as opsonins or amplifying complement-mediated opsonin deposition. Such superimposing phenomenon may be as well modulated by specific and differential nanosurface determinants or by an exclusive or synergic modulation by bystander-bound host proteins. It is relevant to notice that both $\mathrm{C} 4$ and $\mathrm{C} 3$ opsonin deposition on NPs are modulated by the chemical reactivity of their internal thioester bonds with $-\mathrm{OH}$ and $-\mathrm{NH}_{2}$ groups or other nucleophiles expressed by host-exposed NP components (e.g., polymer coats) or by bystander NP-associated proteins. Hence, the final opsonization efficacy may be further increased, depending not only on the extent of initial complement triggers of NP binding (an exquisitely thermodynamic equilibrium step) but also on the overall chemical reactivity of the NP coats and NPbound protein set, which will concur to determine the extent of $\mathrm{C} 3 \mathrm{~b}$ fixation available to $\mathrm{C} 3$ receptors on NP-clearing phagocytes. The chemical reactivity of NP coats and bound proteins is expected to be especially relevant in those cases in which C3b fixation results from genuine AP activation, since this occurs in the absence of initial triggers like antibodies or lectins. Moreover, C3b opsonization may be further modulated by the NP efficacy in favoring or interfering with the association of complementregulating components, such as $\mathrm{C} 4 \mathrm{~b}-$ binding protein $\mathrm{A}(\mathrm{C} 4 \mathrm{BP})$, the complement factor $\mathrm{H}(\mathrm{CFH})$, or factor $\mathrm{H}$-related (FHr) proteins. Overall, present literature suggests that the effective complement cascade activation on NPs can strongly unbalance the initial opsonin/dysopsonin proportions, becoming in several cases a major functional actor in regulating the stealth features of NPs. More in general, we can predict that, due to the above 
variables, opsonins may be differently added to NPs, resulting in a wide spectrum of phagocytosis up-modulation: from almost zero (dysopsonic action prevailing) to moderate effect (opsonins and dysopsonins balanced and reciprocally neutralizing) or, at the opposite extreme, to strong capture when opsonin density overcomes and neutralizes dysopsonin effects.

\section{CONCLUDING REMARKS}

To conclude, as summarized in Figure 7, it is evident from literature that both nude and host protein-modified NPs are characterized by differential phagocytosis ranges, where the ranking can be rearranged. Such phagocytic rates, in general, collapse into a narrower, and tendentially reduced, capture spectrum efficacy in the presence of biofluid, naturally or artificially deprived of pro-opsonic agents. However, since in natural conditions the no-protein medium is not present, the most critic comparison to spot factors improving RES clearance and possibly affecting a nanoformulation half-life in blood, is between control conditions (normal

\section{REFERENCES}

1. Patel HM. Serum opsonins and liposomes: their interaction and opsonophagocytosis. Crit Rev Ther Drug Carrier Syst. (1992) 9:39-90.

2. Moein Moghimi S, Patel HM. Serum opsonins and phagocytosis of saturated and unsaturated phospholipid liposomes. BBA Biomembr. (1989) 984:384-7. doi: 10.1016/0005-2736(89)90307-6

3. Gabizon A, Papahadjopoulos D. Liposome formulations with prolonged circulation time in blood and enhanced uptake by tumors. Proc Natl Acad Sci USA. (1988) 85:6949-53. doi: 10.1073/pnas.85.18.6949

4. Scieszka JF, Cho MJ. Cellular uptake of a fluid-phase marker by human neutrophils from solutions and liposomes. Pharm Res. (1988) 5:352-8. doi: 10.1023/a:1015903510262

5. Allen TM, Hansen C. Pharmacokinetics of stealth versus conventional liposomes: effect of dose. BBA Biomembr. (1991) 1068:133-41. doi: 10.1016/ 0005-2736(91)90201-I

6. Moghimi SM, Muir IS, Illum L, Davis SS, Kolb-Bachofen V. Coating particles with a block co-polymer (poloxamine-908) suppresses opsonization but permits the activity of dysopsonins in the serum. Biochim Biophys Acta. (1993) 1179:157-65. doi: 10.1016/0167-4889(93)90137-e

7. Muir IS, Moghimi SM, Illum L, Davis SS, Davies MC. The effect of block co-polymers on the uptake of model polystyrene microspheres by Kupffer cells- In vitro and in vivo studies. Biochem Soc Trans. (1991) 19:329S. doi: 10.1042/bst019329s

8. Leroux JC, Gravel P, Balant L, Volet B, Anner BM, Allémann E, et al. Internalization of poly(D,L-lactic acid) nanoparticles by isolated human leukocytes and analysis of plasma proteins adsorbed onto the particles. $J$ Biomed Mater Res. (1994) 28:471-81. doi: 10.1002/jbm.820280410

9. Gref R, Lück M, Quellec P, Marchand M, Dellacherie E, Harnisch S, et al. "Stealth" corona-core nanoparticles surface modified by polyethylene glycol (PEG): influences of the corona (PEG chain length and surface density) and of the core composition on phagocytic uptake and plasma protein adsorption. Colloids Surf B Biointerfaces. (2000) 18:301-13. doi: 10.1016/S0927-7765(99) 00156-3

10. Gref R, Domb A, Quellec P, Blunk T, Müller RH, Verbavatz JM, et al. The controlled intravenous delivery of drugs using PEG-coated sterically stabilized nanospheres. Adv Drug Deliv Rev. (1995) 16:215-33. doi: 10.1016/0169409X(95)00026-4

11. Allémann E, Gravel P, Leroux JC, Balant L, Gurny R. Kinetics of blood component adsorption on poly(D,L-lactic acid) nanoparticles: evidence of host fluid normal cell acceptor) with manipulated host fluid or cell acceptors, highlighting the determinant role of specific host NP-bound proteins and specific receptors on acceptor cells.

Once such biochemical phenomenon is delineated, and its assay developed and standardized, a feedback iterative loop may be applied to test coating designs lacking the opsonin deposition, for better stealth nanoformulations.

\section{AUTHOR CONTRIBUTIONS}

All authors equally contributed to text writing and figure assembly.

\section{FUNDING}

This work was supported by the University of Padua (DOR 2019 and 2020 and Progetto SID 2018) to EP and by the European Commission (EU MSCA-ITN project MMBio 721613) to FM.

complement C3 component involvement. J Biomed Mater Res. (1997) 37:229_ 34. doi: 10.1002/(sici)1097-4636(199711)37:2<229::aid-jbm12>3.0.co;2-9

12. Mohamed M, Abu Lila AS, Shimizu T, Alaaeldin E, Hussein A, Sarhan HA, et al. PEGylated liposomes: immunological responses. Sci Technol Adv Mater. (2019) 20:710-24. doi: 10.1080/14686996.2019.1627174

13. Moghimi SM, Andersen AJ, Ahmadvand D, Wibroe PP, Andresen TL, Hunter AC. Material properties in complement activation. Adv Drug Deliv Rev. (2011) 63:1000-7. doi: 10.1016/j.addr.2011.06.002

14. Pallardy MJ, Turbica I, Biola-Vidamment A. Why the immune system should be concerned by nanomaterials? Front Immunol. (2017) 8:544. doi: 10.3389/ fimmu.2017.00544

15. Fadeel B. Hide and seek: nanomaterial interactions with the immune system. Front Immunol. (2019) 10:133. doi: 10.3389/fimmu.2019.00133

16. Boraschi D, Italiani P, Palomba R, Decuzzi P, Duschl A, Fadeel B, et al. Nanoparticles and innate immunity: new perspectives on host defence. Semin Immunol. (2017) 34:33-51. doi: 10.1016/j.smim.2017.08.013

17. Cedervall T, Lynch I, Lindman S, Berggard T, Thulin E, Nilsson H, et al. Understanding the nanoparticle-protein corona using methods to quantify exchange rates and affinities of proteins for nanoparticles. Proc Natl Acad Sci USA. (2007) 104:2050-5. doi: 10.1073/pnas.0608 582104

18. Schöttler S, Landfester K, Mailänder V. Controlling the stealth effect of nanocarriers through understanding the protein corona. Angew Chem Int Ed Engl. (2016) 55:8806-15. doi: 10.1002/anie.201602233

19. Tenzer S, Docter D, Rosfa S, Wlodarski A, Kuharev J, Rekik A, et al. Nanoparticle size is a critical physicochemical determinant of the human blood plasma corona: a comprehensive quantitative proteomic analysis. ACS Nano. (2011) 5:7155-67. doi: 10.1021/nn201950e

20. Walkey CD, Olsen JB, Song F, Liu R, Guo H, Olsen DWH, et al. Protein corona fingerprinting predicts the cellular interaction of gold and silver nanoparticles. ACS Nano. (2014) 8:2439-55. doi: 10.1021/nn40 $6018 \mathrm{q}$

21. Lundqvist M, Stigler J, Elia G, Lynch I, Cedervall T, Dawson KA. Nanoparticle size and surface properties determine the protein corona with possible implications for biological impacts. Proc Natl Acad Sci USA. (2008) 105:1426570. doi: 10.1073/pnas.0805135105

22. Monopoli MP, Walczyk D, Campbell A, Elia G, Lynch I, Baldelli Bombelli F, et al. Physical-chemical aspects of protein corona: relevance to in vitro and in vivo biological impacts of nanoparticles. J Am Chem Soc. (2011) 133:2525-34. doi: 10.1021/ja107583h 
23. Walczyk D, Bombelli FB, Monopoli MP, Lynch I, Dawson KA. What the cell "sees" in bionanoscience. J Am Chem Soc. (2010) 132:5761-8. doi: 10.1021/ ja910675v

24. Pelaz B, del Pino P, Maffre P, Hartmann R, Gallego M, Rivera-Fernández S, et al. Surface functionalization of nanoparticles with polyethylene glycol: effects on protein adsorption and cellular uptake. ACS Nano. (2015) 9:69967008. doi: 10.1021/acsnano.5b01326

25. Lesniak A, Fenaroli F, Monopoli MP, Åberg C, Dawson KA, Salvati A. Effects of the presence or absence of a protein corona on silica nanoparticle uptake and impact on cells. ACS Nano. (2012) 6:5845-57. doi: 10.1021/nn300223w

26. Dell'Orco D, Lundqvist M, Oslakovic C, Cedervall T, Linse S. Modeling the time evolution of the nanoparticle-protein corona in a body fluid. PLoS One. (2010) 5:e10949. doi: 10.1371/journal.pone.0010949

27. Fedeli C, Segat D, Tavano R, Bubacco L, De Franceschi G, de Laureto PP, et al. The functional dissection of the plasma corona of SiO2-NPs spots histidine rich glycoprotein as a major player able to hamper nanoparticle capture by macrophages. Nanoscale. (2015) 7:17710-28. doi: 10.1039/c5nr 05290d

28. Tavano R, Gabrielli L, Lubian E, Fedeli C, Visentin S, Polverino De Laureto $\mathrm{P}$, et al. C1q-mediated complement activation and C3 opsonization trigger recognition of stealth poly(2-methyl-2-oxazoline)-coated silica nanoparticles by human phagocytes. ACS Nano. (2018) 12:5834-47. doi: 10.1021/acsnano. $8 \mathrm{~b} 01806$

29. Francia V, Yang K, Deville S, Reker-Smit C, Nelissen I, Salvati A. Corona composition can affect the mechanisms cells use to internalize nanoparticles. ACS Nano. (2019) 13:11107-21. doi: 10.1021/acsnano.9b03824

30. Hellstrand E, Lynch I, Andersson A, Drakenberg T, Dahlbäck B, Dawson $\mathrm{KA}$, et al. Complete high-density lipoproteins in nanoparticle corona. FEBS J. (2009) 276:3372-81. doi: 10.1111/j.1742-4658.2009.07062.x

31. Lima T, Bernfur K, Vilanova M, Cedervall T. Understanding the lipid and protein corona formation on different sized polymeric nanoparticles. Sci Rep. (2020) 10:1129. doi: 10.1038/s41598-020-57943-6

32. Von Zychlinski A, Williams M, McCormick S, Kleffmann T. Absolute quantification of apolipoproteins and associated proteins on human plasma lipoproteins. J Proteomics. (2014) 106:181-90. doi: 10.1016/j.jprot.2014.04.030

33. Singh SA, Aikawa M. Unbiased and targeted mass spectrometry for the HDL proteome. Curr Opin Lipidol. (2017) 28:68-77. doi: 10.1097/MOL. 0000000000000374

34. Docter D, Distler U, Storck W, Kuharev J, Wünsch D, Hahlbrock A, et al. Quantitative profiling of the protein coronas that form around nanoparticles. Nat Protoc. (2014) 9:2030-44. doi: 10.1038/nprot.2014.139

35. Hidalgo A, Cruz A, Pérez-Gil J. Pulmonary surfactant and nanocarriers: toxicity versus combined nanomedical applications. Biochim Biophys acta Biomembr. (2017) 1859:1740-8. doi: 10.1016/j.bbamem.2017.04.019

36. Raesch SS, Tenzer S, Storck W, Rurainski A, Selzer D, Ruge CA, et al. Proteomic and lipidomic analysis of nanoparticle corona upon contact with lung surfactant reveals differences in protein, but not lipid composition. ACS Nano. (2015) 9:11872-85. doi: 10.1021/acsnano.5b04215

37. Whitwell H, Mackay RM, Elgy C, Morgan C, Griffiths M, Clark H, et al. Nanoparticles in the lung and their protein corona: the few proteins that count. Nanotoxicology. (2016) 10:1385-94. doi: 10.1080/17435390.2016.1218080

38. Madsen J, Mollenhauer J, Holmskov U. Review: Gp-340/DMBT1 in mucosal innate immunity. Innate Immun. (2010) 16:160-7. doi: 10.1177/ 1753425910368447

39. Solorio-Rodríguez A, Escamilla-Rivera V, Uribe-Ramírez M, Chagolla A, Winkler R, García-Cuellar CM, et al. A comparison of the human and mouse protein corona profiles of functionalized SiO2 nanocarriers. Nanoscale. (2017) 9:13651-60. doi: 10.1039/c7nr04685e

40. Fedeli C, Segat D, Tavano R, De Franceschi G, De Laureto PP, Lubian E, et al. Variations of the corona HDL:albumin ratio determine distinct effects of amorphous $\mathrm{SiO} 2$ nanoparticles on monocytes and macrophages in serum. Nanomedicine. (2014) 9:2481-97. doi: 10.2217/nnm.14.22

41. Lara S, Alnasser F, Polo E, Garry D, Lo Giudice MC, Hristov DR, et al. Identification of receptor binding to the biomolecular corona of nanoparticles. ACS Nano. (2017) 11:1884-93. doi: 10.1021/acsnano.6b07933

42. Ritz S, Schöttler S, Kotman N, Baier G, Musyanovych A, Kuharev J, et al. Protein corona of nanoparticles: distinct proteins regulate the cellular uptake. Biomacromolecules. (2015) 16:1311-21. doi: 10.1021/acs.biomac.5b00108
43. Kim HR, Gil S, Andrieux K, Nicolas V, Appel M, Chacun H, et al. Lowdensity lipoprotein receptor-mediated endocytosis of PEGylated nanoparticles in rat brain endothelial cells. Cell Mol Life Sci. (2007) 64:356-64. doi: 10.1007/ s00018-007-6390-x

44. Kim HR, Andrieux K, Gil S, Taverna M, Chacun H, Desmaële D, et al. Translocation of poly(ethylene glycol-co-hexadecyl)cyanoacrylate nanoparticles into rat brain endothelial cells: role of apolipoproteins in receptor-mediated endocytosis. Biomacromolecules. (2007) 8:793-9. doi: 10. 1021/bm060711a

45. Schöttler S, Becker G, Winzen S, Steinbach T, Mohr K, Landfester K, et al. Protein adsorption is required for stealth effect of poly(ethylene glycol)- and poly(phosphoester)-coated nanocarriers. Nat Nanotechnol. (2016) 11:372-7. doi: 10.1038/nnano.2015.330

46. Selvestrel F, Moret F, Segat D, Woodhams JH, Fracasso G, Echevarria IMR, et al. Targeted delivery of photosensitizers: efficacy and selectivity issues revealed by multifunctional ORMOSIL nanovectors in cellular systems. Nanoscale. (2013) 5:6106-16. doi: 10.1039/c3nr00402c

47. Aoyama M, Hata K, Higashisaka K, Nagano K, Yoshioka Y, Tsutsumi Y. Clusterin in the protein corona plays a key role in the stealth effect of nanoparticles against phagocytes. Biochem Biophys Res Commun. (2016) 480:690-5. doi: 10.1016/j.bbrc.2016.10.121

48. Simon J, Müller J, Ghazaryan A, Morsbach S, Mailänder V, Landfester K. Protein denaturation caused by heat inactivation detrimentally affects biomolecular corona formation and cellular uptake. Nanoscale. (2018) 10:21096-105. doi: 10.1039/c8nr07424k

49. Kaufmann SHE. Immunology's foundation: the 100-year anniversary of the Nobel Prize to Paul Ehrlich and Elie Metchnikoff. Nat Immunol. (2008) 9:705-12. doi: 10.1038/ni0708-705

50. Thiele L, Diederichs JE, Reszka R, Merkle HP, Walter E. Competitive adsorption of serum proteins at microparticles affects phagocytosis by dendritic cells. Biomaterials. (2003) 24:1409-18. doi: 10.1016/S0142-9612(02) 00525-2

51. Treuel L, Brandholt S, Maffre P, Wiegele S, Shang L, Nienhaus GU. Impact of protein modification on the protein corona on nanoparticles and nanoparticle-cell interactions. ACS Nano. (2014) 8:503-13. doi: 10.1021/ nn405019v

52. Latorre A, Latorre A, Castellanos M, Rodriguez Diaz C, Lazaro-Carrillo A, Aguado T, et al. Multifunctional albumin-stabilized gold nanoclusters for the reduction of cancer stem cells. Cancers. (2019) 11:969. doi: 10.3390/ cancers 11070969

53. Larsen MT, Kuhlmann M, Hvam ML, Howard KA. Albumin-based drug delivery: harnessing nature to cure disease. Mol Cell Ther. (2016) 4:3. doi: 10.1186/s40591-016-0048-8

54. Merle NS, Church SE, Fremeaux-Bacchi V, Roumenina LT. Complement system part I - molecular mechanisms of activation and regulation. Front Immunol. (2015) 6:262. doi: 10.3389/fimmu.2015.00262

55. Ricklin D, Hajishengallis G, Yang K, Lambris JD. Complement: a key system for immune surveillance and homeostasis. Nat Immunol. (2010) 11:785-97. doi: $10.1038 /$ ni. 1923

56. Leroux JC, De Jaeghere F, Anner B, Doelker E, Gurny R. An investigation on the role of plasma and serum opsonins on the internalization of biodegradable poly(D,L-lactic acid) nanoparticles by human monocytes. Life Sci. (1995) 57:695-703. doi: 10.1016/0024-3205(95)00321-v

57. Pham CTN, Mitchell LM, Huang JL, Lubniewski CM, Schall OF, Killgore JK, et al. Variable antibody-dependent activation of complement by functionalized phospholipid nanoparticle surfaces. J Biol Chem. (2011) 286:123-30. doi: 10. 1074/jbc.M110.180760

58. Moghimi SM, Simberg D. Complement activation turnover on surfaces of nanoparticles. Nano Today. (2017) 15:8-10. doi: 10.1016/j.nantod.2017.03.001

59. Gifford G, Vu VP, Banda NK, Holers VM, Wang G, Groman EV, et al. Complement therapeutics meets nanomedicine: overcoming human complement activation and leukocyte uptake of nanomedicines with soluble domains of CD55. J Control Release. (2019) 302:181-9. doi: 10.1016/j.jconrel. 2019.04.009

60. Moein Moghimi S, Simberg D, Skotland T, Yaghmur A, Christy Hunter A. The interplay between blood proteins, complement, and macrophages on nanomedicine performance and responses. J Pharmacol Exp Ther. (2019) 370:581-92. doi: 10.1124/jpet.119.258012 
61. Fine DP. Comparison of ethyleneglycoltetraacetic acid and its magnesium salt as reagents for studying alternative complement pathway function. Infect Immun. (1977) 16:124-8. doi: 10.1128/iai.16.1.124-1 28.1977

62. Banda NK, Mehta G, Chao Y, Wang G, Inturi S, Fossati-Jimack $\mathrm{L}$, et al. Mechanisms of complement activation by dextran-coated superparamagnetic iron oxide (SPIO) nanoworms in mouse versus human serum. Part Fibre Toxicol. (2014) 11:64. doi: 10.1186/s12989-01 4-0064-2

63. Inturi S, Wang G, Chen F, Banda NK, Holers VM, Wu L, et al. Modulatory role of surface coating of superparamagnetic iron oxide nanoworms in complement opsonization and leukocyte uptake. ACS Nano. (2015) 9:1075868. doi: 10.1021/acsnano.5b05061

64. Palaniyar N. Antibody equivalent molecules of the innate immune system: parallels between innate and adaptive immune proteins. Innate Immun. (2010) 16:131-7. doi: 10.1177/1753425910370498

65. Ren J, Cai R, Wang J, Daniyal M, Baimanov D, Liu Y, et al. Precision nanomedicine development based on specific opsonization of human cancer patient-personalized protein coronas. Nano Lett. (2019) 19:4692-701. doi: 10.1021/acs.nanolett.9b01774

66. Pondman KM, Pednekar L, Paudyal B, Tsolaki AG, Kouser L, Khan HA, et al. Innate immune humoral factors, $\mathrm{Clq}$ and factor $\mathrm{H}$, with differential pattern recognition properties, alter macrophage response to carbon nanotubes. Nanomedicine. (2015) 11:2109-18. doi: 10.1016/j.nano.2015. 06.009

67. Belime A, Gravel E, Brenet S, Ancelet S, Caneiro C, Hou Y, et al. Mode of PEG coverage on carbon nanotubes affects binding of innate immune protein C1q. J Phys Chem B. (2018) 122:757-63. doi: 10.1021/acs.jpcb. $7 \mathrm{~b} 06596$

68. Kouser L, Paudyal B, Kaur A, Stenbeck G, Jones LA, Abozaid SM, et al. Human properdin opsonizes nanoparticles and triggers a potent pro-inflammatory response by macrophages without involving complement activation. Front Immunol. (2018) 9:131. doi: 10.3389/fimmu.2018.00131

69. Vu VP, Gifford GB, Chen F, Benasutti H, Wang G, Groman EV, et al. Immunoglobulin deposition on biomolecule corona determines complement opsonization efficiency of preclinical and clinical nanoparticles. Nat Nanotechnol. (2019) 14:260-8. doi: 10.1038/s41565-018-0344-3

70. Rezaei G, Daghighi SM, Raoufi M, Esfandyari-Manesh M, Rahimifard M, Mobarakeh VI, et al. Synthetic and biological identities of polymeric nanoparticles influencing the cellular delivery: an immunological link. J Colloid Interface Sci. (2019) 556:476-91. doi: 10.1016/j.jcis.2019. 08.060

71. Hidalgo A, Cruz A, Pérez-Gil J. Barrier or carrier? Pulmonary surfactant and drug delivery. Eur J Pharm Biopharm. (2015) 95:117-27. doi: 10.1016/j.ejpb. 2015.02.014

72. Kishore U, Greenhough TJ, Waters P, Shrive AK, Ghai R, Kamran MF, et al. Surfactant proteins SP-A and SP-D: structure, function and receptors. Mol Immunol. (2006) 43:1293-315. doi: 10.1016/j.molimm.2005.08.004
73. McKenzie Z, Kendall M, Mackay R-M, Whitwell H, Elgy C, Ding P, et al. Surfactant protein A (SP-A) inhibits agglomeration and macrophage uptake of toxic amine modified nanoparticles. Nanotoxicology. (2015) 9:952-62. doi: $10.3109 / 17435390.2014 .992487$

74. Ruge CA, Kirch J, Cañadas O, Schneider M, Perez-Gil J, Schaefer UF, et al. Uptake of nanoparticles by alveolar macrophages is triggered by surfactant protein A. Nanomed Nanotechnol Biol Med. (2011) 7:690-3. doi: 10.1016/j. nano.2011.07.009

75. Honda Y, Takahashi H, Shijubo N, Kuroki Y, Akino T. Surfactant proteinA concentration in bronchoalveolar lavage fluids of patients with pulmonary alveolar proteinosis. Chest. (1993) 103:496-9. doi: 10.1378/chest.103.2.496

76. Sato T, Saito Y, Chikuma M, Saito Y, Nagai S. Determination of albumin in bronchoalveolar lavage fluid by flow-injection fluorometry using chromazurol S. Biol Pharm Bull. (2008) 31:336-9. doi: 10.1248/bpb.31.336

77. Ruge CA, Hillaireau H, Grabowski N, Beck-Broichsitter M, Cañadas O, Tsapis N, et al. Pulmonary surfactant protein A-mediated enrichment of surface-decorated polymeric nanoparticles in alveolar macrophages. Mol Pharm. (2016) 13:4168-78. doi: 10.1021/acs.molpharmaceut. $6 \mathrm{~b} 00773$

78. Schulze C, Schaefer UF, Ruge CA, Wohlleben W, Lehr CM. Interaction of metal oxide nanoparticles with lung surfactant protein A. Eur J Pharm Biopharm. (2011) 77:376-83. doi: 10.1016/j.ejpb.2010. 10.013

79. Pondman KM, Paudyal B, Sim RB, Kaur A, Kouser L, Tsolaki AG, et al. Pulmonary surfactant protein SP-D opsonises carbon nanotubes and augments their phagocytosis and subsequent pro-inflammatory immune response. Nanoscale. (2017) 9:1097-109. doi: 10.1039/c6nr $08807 \mathrm{~d}$

80. Kendall M, Ding P, MacKay RM, Deb R, McKenzie Z, Kendall K, et al. Surfactant protein D (SP-D) alters cellular uptake of particles and nanoparticles. Nanotoxicology. (2013) 7:963-73. doi: 10.3109/17435390.2012. 689880

81. Wang G, Griffin JI, Inturi S, Brenneman B, Banda NK, Holers VM, et al. In vitro and in vivo differences in murine third complement component (c3) opsonization and macrophage/leukocyte responses to antibody-functionalized iron oxide nanoworms. Front Immunol. (2017) 8:151. doi: 10.3389/fimmu. 2017.00151

Conflict of Interest: The authors declare that the research was conducted in the absence of any commercial or financial relationships that could be construed as a potential conflict of interest.

Copyright (c) 2020 Papini, Tavano and Mancin. This is an open-access article distributed under the terms of the Creative Commons Attribution License (CC BY). The use, distribution or reproduction in other forums is permitted, provided the original author(s) and the copyright owner(s) are credited and that the original publication in this journal is cited, in accordance with accepted academic practice. No use, distribution or reproduction is permitted which does not comply with these terms. 